Article

\title{
Democratising Smart Cities? Penta-Helix Multistakeholder Social Innovation Framework
}

\author{
Igor Calzada ${ }^{1,2}$ (D) \\ 1 Urban Transformations ESRC \& Future of Cities Programmes, COMPAS, University of Oxford, \\ 58 Banbury Road, Oxford OX2 6QS, UK; igor.calzada@compas.ox.ac.uk; Tel.: +44-7887-661925 \\ 2 Digital Economy Unit \& Centre for Advanced Studies (CAS), DG Joint Research Centre (JRC), \\ European Commission, Via Fermi 2749, 21027 Ispra, Italy
}

Received: 8 September 2020; Accepted: 28 September 2020; Published: 6 October 2020

\begin{abstract}
The smart cities policy approach has been intensively implemented in European cities under the Horizon 2020 programme. However, these implementations not only reduce the interdependencies among stakeholders to technocratic Public-Private-Partnership (PPP) models, but also fail to question the identities of strategic stakeholders and how they prioritise their business/social models. These aspects are putting democracy at stake in smart cities. Therefore, this article aims to unfold and operationalise multistakeholders' policy frameworks from the social innovation perspective by suggesting the ex-novo penta-helix framework-including public, private, academia, civic society, and social entrepreneurs/activists- to extend the triple and quadruple-helix frameworks. Based on fieldwork action research conducted from February 2017 to December 2018-triangulating desk research, 75 interviews, and three validation workshops-this article applies the penta-helix framework to map out five strategic dimensions related to (i) multistakeholder helix framework and (ii) the resulting business/social models comparatively in three follower cities of the H2020-Replicate project: Essen (Germany), Lausanne (Switzerland), and Nilüfer (Turkey). For each case study, the findings reveal: (i) a unique multistakeholder composition, (ii) diverse preferences on business/social models, (iii) a regular presence of the fifth helix as intermediaries, and (iv) the willingness to experiment with democratic arrangements beyond the hegemonic PPP.
\end{abstract}

Keywords: smart cities; social innovation; penta-helix; multistakeholder; H2020; Europe; democracy; PPP; action research; fieldwork

\section{Introduction: Democratising the Technocratic Smart City}

Smartness in cities cannot be more technocratic than democratic [1]. Albeit over recent years, smart city has become eminently a mainstream technocratic concept in European policy agendas [2,3]. These agendas, in turn, have taken for granted the meaning of stakeholders without further questioning who the term actually references, which puts at stake both urban democracy and the related political decisions for the city [4-9].

In addition, increasingly autonomous and invisible algorithms have made it even harder for city authorities to detect and scrutinise their impartiality status, resulting in a technocratic governance push of the smart city [10,11]. Kitchin [12] (p. 9) defines technocratic governance as the procedure by which "all aspects of a city can be measured and monitored and treated as technical problems that can be addressed through technical solutions." Thus, the aggregated use of digital data to monitor, surveil, and nudge citizens has resulted in an intrinsic version of the technocratic smart city [13-15], which pervasively bypasses the democratic accountability to which stakeholders are entitled. Despite these negative side effects, smart cities have remained the focus of urban policy and decision-makers worldwide, as a broad rubric for using the so-called stakeholder and citizen 
engagement practices orientated towards the management in such techno-deterministic - and more bluntly, less democratic — and, thus, further platformised urban realms [16-18].

Against this backdrop, the smart cities policy approach has been intensively implemented in several European cities under the policy umbrella of the H2020-Smart Cities and Communities (H2020-SCC) framework funded by the European Commission [19-25]. Particularly since 2015, 17 lighthouse projects-involving 46 lighthouses and 71 follower cities-have been laying out the European H2020-SCC policy scheme [26]. These lighthouse projects, according to the related institutional discourse, aim to deliver smart technologies to municipalities by demonstrating that technologies on energy, mobility, and ICT can be a cost-effective way to tackle some of the most profound social, political, democratic, economic, institutional, and environmental issues that current and future generations are likely to face.

Nonetheless, until very recently, the hegemonic policy discourse in the European H2020-SCC policy scheme has been reduced to the economic value it generates through technocratic partnerships with powerful public and private actors: Public-Private-Partnerships (PPP) [27-33]. Beyond these cost-effective PPP models [27,32], which stem from the institutional discourse, little has been questioned about the strategic stakeholders who have been formulating, uniquely and contextually, the smart city priorities [31,34,35]. In fact, the European Commission, as part of its European Innovation Partnerships (EIPs) in H2020-SCC, encourages cities, industries, SMEs, and communities-without clarifying which stakeholders constitute these communities and what role they play-to come together to form an alliance consequential enough to build inclusive citizen-focused smart cities [36].

According to Harvey [37] (p. 2), "smart city and the new urbanism movements build an image of the community and a rhetoric of place-based civic pride and consciousness for those who do not need it, while abandoning others in need to their underclass fate." This statement intertwines with the criticism on the technocratic European smart city model initially advocated by the European Commission's H2020-SCC policy scheme [38-41]. Through the scheme, the democratic representation of stakeholders is reduced to being labelled as "citizen-focused smart cities rooted in pragmatic, instrumental, and paternalistic discourses and practices rather than those of social rights, political citizenship, and the common good" [42] (p. 1).

Furthermore, the perspective of an increase in the already remarkable amount of data being controlled by artificial intelligence tools and devices owned by multinational corporations may further exacerbate already pervasive social inequalities, marginalising the most voiceless and vulnerable stakeholders in smart cities [43-46]. This reality has aggravated the already controversial technocratic smart city model and the related debate, raising questions about who benefits and makes such political determinations.

Thus, the point of departure and the aim of this article is the willingness to illuminate and clarify the methodological discussion on the helix frameworks from the Social Innovation (SI) perspective via extending the triple and quadruple-helix frameworks by suggesting an evidence-based ex-novo framework called penta-helix [47-52]. Penta-helix defines as a joint interaction of the four established helixes of the so-called quadruple-helix (the public sector, the private sector, academia, and civic society) being intermediated and activated by the fifth helix (social entrepreneurs/activists). Accordingly, this article operationally responds to two intertwined research questions related to the democratic representation and the varied power relations among stakeholders: First, how can we map out, comparatively in three cities, the composition of a multistakeholder policy framework based on SI (and the resulting business/social models), particularly enhancing the existing triple- and quadruple-helix frameworks. Second, consequently, how can we further incorporate the dynamic and transformational aspect in smart cities through intermediaries as collaborative capacity builders and the essential transformational agency for SI to occur [53].

In an attempt to shed light on these two research questions, this article operationalises the penta-helix framework and explores research avenues on how to further approach broad democratic representation and agency in smart cities. The article, in doing so, aims to unfold the unique 
multistakeholder composition through five strategic dimensions, by comparing three follower cities of the Replicate H2020-SCC project-Essen (Germany), Lausanne (Switzerland), and Nilüfer (Turkey) - based on the results gathered through intensive action research fieldwork undertaken from February 2017 to December 2018. The three follower cities aimed to look into replicating interventions in their cities [54]. The methodology ensured (i) the inclusion of the widest diversity of potential strategic stakeholders in each city that regularly, actively, and democratically engaged in the formulations of smart city priorities and, consequently, (ii) the mapping out of the multistakeholder policy framework using the penta-helix. The assumption lies in the idea that the broader a composition of stakeholders in a given smart city, the better democratic representation the smart city intervention may achieve. This article presents the empirical results obtained by conducting triangulation methodology in three European cities through three intertwined action research techniques deployed in each case: (i) desk research, (ii) 25 in-depth interviews, and (iii) one validation workshop encompassing 25 strategic stakeholders.

The article is structured as follows: The next section presents the literature review of SI, the third section discusses the methodology of the penta-helix carried out in the three case studies, and the fourth section compares and examines the empirical results. The final section concludes with the main results and offers an array of research avenues to continue exploring how SI may enhance the democratisation in smart cities [55].

\section{Literature Review: Social Innovation (SI) Perspective}

\subsection{Social Innovation (SI)}

Despite the abundant literature about SI, the notion may be blurred too much in the current policy debate [56-73]. As Mihci [74] (p. 18) highlights, insofar as "many theoretical approaches, ideas and practices labelled under the category of SI have relatively little in common", such a vagueness and fuzziness might make the intervention process even more complex and challenging.

In this article, though, SI-defined as the capacity to elaborate alternative discourses and actions that are counter-hegemonic in terms of resistance and/or innovative transformations-plays an important role by generating the intermediation conditions for further democratic decision-making processes for urban and technological adoptions in smart cities [75,76]. SI, thus, offers a critique of the dominance of market-based logics (also embodied through PPP) and data extractivism in the age of liberalism [77], which consequently opens up a promising field of research to revisit helix frameworks that enable intermediation conditions among stakeholders to better achieve a democratic representation of varied power relations [78]. Moreover, according to Moulaert and MacCallum [64] SI revolves around "the idea that society's capacity to attend to human needs is founded on connecting people in ways that promote understanding, reciprocity, and cooperation-that is, on creating the conditions for collective action" (p. 3). Intermediation conditions for collective action as this article shows with a penta-helix multistakeholder SI framework.

Nonetheless, despite that these intermediation conditions need to be thoroughly prepared by incorporating a wider range of stakeholders operating in diverse domains or helixes, it cannot be expected that only incorporating several diverse (even marginal) actors to the socio-political game of the smart city will generate a democratic outcome [43]. In fact, SI suggests mediation and translation between network actors or helixes [75], which may have different interests and understandings of the same urban issues and domains [37]. In this direction, recent projects, such as Smart Urban Intermediaries [53], are exploring this path-complementing the active role of social entrepreneurs and activists in local neighbourhoods as an integral part of stimulating civic society in cross-fertilisation with the public sector, the private sector, and even sometimes academia.

Given the current multistakeholder dynamics in regional innovation systems occurring in European cities and regions under the policy scheme of H2020-SCC, this article argues that transformative alliances among the public sector, private sector, academia, and civic society are increasingly 
including — consciously but also sometimes unwittingly-the emerging fifth helix. The fifth helix is embodied by social entrepreneurs and activists-who play the role of intermediaries, bricoleurs, brokers, and/or assemblers-acting as the main driver of change and, most importantly, operating in the borders by connecting the four entities encompassing the quadruple-helix as pollinisers and cross-sectoral ambassadors [79]. Hence, this article-by applying the penta-helix framework to a comparative study - suggests that the triple-helix [80] alone cannot sufficiently activate unpredictable and experimental dynamics owing to the fixed and technocratic nature of the interplay among stakeholders, nor can the quadruple-helix [81] leverage any intrinsic transformational reaction by itself since it is based on an institutionalised bottom-up process where citizens might react passively to suggested initiatives.

However, acknowledging the novelty and the early stage of this scientific approach, and that helix frameworks methodologically only represent ideal types [82], this article considers that further research is required to explore the profiles, motivations, modes of interaction, and transformative conditions of such intermediation produced by the fifth helix. This article applies the proposed penta-helix framework-preliminarily introduced in previous publications by the author [52]—-to the three aforementioned city cases in order to operationalise SI through helix frameworks, which essentially result in a diverse set of business/social models. By opening up a plethora of potential interactions among diverse stakeholders, this article suggests that cities may be willing to further experiment with adopting one or another business/social model, without necessarily reducing the chances to create hegemonic PPPs.

Thus, to methodologically operationalise stakeholders among helix frameworks and the related interactions among them that result in a diverse set of business/social models-albeit avoiding normative determinism on further assumptions-this section presents two intertwined literature reviews stemming from SI by focusing on the intermediation that enables the penta-helix framework conditions. The first subsection revolves around the literature on rethinking multistakeholder helix frameworks by exploring the potential features of triple-, quadruple-, and penta-helix frameworks based on the notion of the urban commons, particularly through data commons as an updated timely trend in several smart cities $[83,84]$. The second subsection examines the literature on the resulting five business/social models that stem from the multistakeholder helix frameworks.

\subsection{Rethinking Multistakeholder Helix Frameworks from the SI Perspective: Triple-, Quadruple-, and Penta-Helix}

The triple-helix framework was developed to conceptualise public innovation and the flow of knowledge in open innovation systems [85]. Initially focused on technological innovation that benefits economic development, the triple-helix framework was useful for the interconnectedness among universities, industry, and government [76]. In those days, it could be seen as an almost disruptive idea. Soon, however, the institutional arrangements established in the name of the triple-helix became more separated and conventional. The inventions were supposed to be generated in what has been called the knowledge infrastructure (universities), developed through the support structure (usually tax-financed incubators), and finally commercialised in the production structure (private sector as business-as-usual). Several authors theorised the triple-helix as the framework (made up of private/industry, public/government, and academia/university) that enabled researchers to study the knowledge base of an urban economy [86-90].

However, neither dynamic and pervasive SI processes nor civic society as an entity or helix were included in this analysis, insofar as the definition of smart city governance only considered the fixed structure fuelled "by academia, industry, and government" [91] (p. 7). The definition also excluded methodologically civic society (quadruple-helix) and further omitted the assemblage role that social entrepreneurs and activists (penta-helix) may play towards further democratic notions of smart cities. In addition, Deakin [91] (p. 1) considers the triple-helix framework sufficient to "cultivate the environmental capacity, ecology, and vitality of those spaces which the direct democracy 
of their participatory governance opens up, add value to and construct." On the other hand, this article emphasises the necessary connections among stakeholders through the active role of the pervasive fifth helix between social entrepreneurship/activists in the policy experimentation process by avoiding narrow interpretations under the banner of SI [70]. Paradoxically, though, if wrongly employed, SI can seemingly even reinforce ongoing dynamics of welfare state retrenchment instead of its re-activation by reducing the scope to enhance the position of SI as a better placed paradigm to develop sustainable responses to contemporary societal challenges, compared to free-market solutions [92] and to neoliberal governing strategies [93] usually embedded in the so-called PPP.

By acknowledging the limited scope of the triple-helix framework [76,94], Goddard and Kempton [95] describe the quadruple-helix framework as a partnership convened by universities as key civic institutions to shape the future development of their cities. They suggest that global knowledge locked up in universities could be mobilised to anchor the university locally in the city by using urban foresight methodologies. In essence, this approach challenges the traditional linear models of science and technology push approach to city development through research commercialisation, which has been embraced by governments through the support of triple-helix partnerships between the state, universities, and businesses and the creation of urban science parks [88,96]. Thus, the 'civic university' is suggested as contrasting the traditional university, insofar as there are strong overlaps between the three domains of teaching, research, and societal engagement and the adoption of a holistic view of city development. Hence, the quadruple-helix framework might include diverse ways that citizens and stakeholders can actually benefit from recent developments in urban technologies [97]. Nonetheless, the quadruple-helix framework has sometimes revealed that the initiatives are pushed by institutions, resulting in poor or even inexistent social mobilisation [98-101].

Furthermore, neither the triple- nor the quadruple-helix frameworks can explain the articulation of a deeper transformational democratic disruption entirely led and governed by an intermediated collective intelligence. In such frameworks, beside market creation and competitiveness imperatives, little is left for experimenting among entrepreneurial co-operative networks of individuals and civic groups [102,103]. This fact could be seen as a systemic innovative spark towards tackling the lack of political engagement and democratic representation. The penta-helix framework, thus, suggests the fifth helix, an assemblage, being diluted in the other four helixes while claiming the need to expand the understanding of the data-driven smart city and focusing on the identification of the urban assets as data with full consideration now as a public good or as data commons [84].

Inevitably, the penta-helix framework resonates with the narratives of the urban commons [104], which has recently been reinterpreted, most importantly, in the aftermath of the algorithmic disruptive tsunami, as data commons $[83,84]$, in which data is seen as a common infrastructure beyond the PPP hegemony. Regarding data commons, Bollier [105] suggests that citizens could retain control of data related to the smart services that matter to them, instead of data related to businesses or bureaucracy. The data commons, thus, go beyond state-market solutions by asking whether another type of city is possible - that is, a third way between the state and the market, a city not dominated by the PPP. Unsurprisingly, then, a techno-political debate appears to be gathering around theses ever-more-frequent conflicts that lack an adequate response in the traditional market-state dichotomy. A nondeterministic way to start exploring new socially innovative outcomes could be a transition from the triple- and quadruple-helixes to the penta-helix, in order to enhance the scope for resulting business/social models among stakeholders.

In addition, data-driven sensitive urban environments require the valuable role of intermediaries such as social entrepreneurs and activists [16] (i.e., transformers or bricoleurs). Ultimately, it is essential to bring back the social ties that modern hyper-connected societies have dramatically weakened through the spread of data-rich fragmented environments [106]. Therefore, it is vital to rethink multistakeholder helix strategies by ensuring the complete democratic representation of diverse voices from each helix. This representation would reflect a wide range of voices in a community without relegating any to institutional settings, yet it cannot occur while taking for granted the valuable roles of 
proactive stakeholders, who set up new collective connections based on the interplay among a diverse set of interests, imaginaries, and practices [76,107-109].

Hence, the inclusion of the fifth helix, broadly understood as those agents playing the role of transformational intermediaries (i.e., brokers or assemblers) in pursuit of social entrepreneurship [36] and activism, connects directly to these early adopters with an ethical and socio-political awareness of social justice and democracy. The penta-helix (shown in Figure 1), in contrast to the institutional structuralist triple- and quadruple-helix, is novel as its contribution includes social entrepreneurs, activists, assemblers, or bricoleurs as an additional helix, which emphasises the active role of citizenship as an agency of systemic, bottom-up, and disruptive SI [110]. This fifth helix is the key driver not only to transform and democratise the smart city concept, but also to experiment across institutional boundaries in search of the urban commons [111].

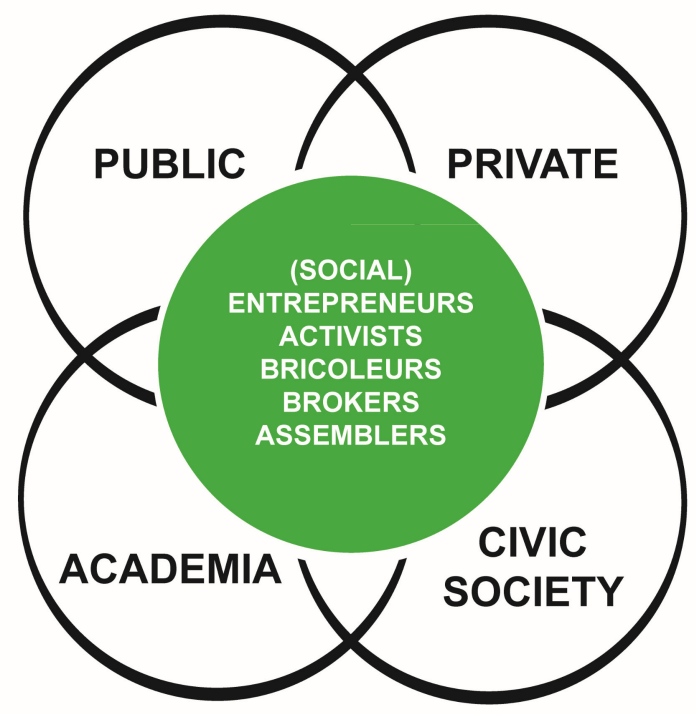

Figure 1. Penta-helix multistakeholder framework.

As a result of the triangulation fieldwork action research conducted, this article suggests the penta-helix framework for considering people and/or organisations as playing the key role of connecting the entities of the quadruple-helix by fulfilling the following functions: (i) transfer, receive, and integrate knowledge across helixes in a network; (ii) bring across networks; (iii) nurture the ability to cooperate among stakeholders by gaining support of leadership, structuring transformative alliances, and working under different jurisdictions; (iv) act as 'network builders' by bringing together resources, users, and developers; (v) behave as global carriers of best practices, standards, and institutionalised learning such as lobbying, which are informed by, and in turn inform, concrete local and regional projects; and (vi) ultimately, recognise plural visions by working out societal challenges (Table 1).

Table 1. Literature Review: Rethinking Multistakeholder Helix Frameworks from the SI Perspective.

\begin{tabular}{|c|c|c|c|}
\hline & \multicolumn{3}{|c|}{ Multistakeholder Framework Analysis } \\
\hline & $\begin{array}{l}\text { Triple-Helix } \\
\text { (TH) }\end{array}$ & $\begin{array}{l}\text { Quadruple-Helix } \\
\text { (QH) }\end{array}$ & $\begin{array}{c}\text { Penta-Helix } \\
(\mathrm{PH})\end{array}$ \\
\hline Stakeholders & $\begin{array}{c}\text { Public } \\
\text { Private } \\
\text { Academia }\end{array}$ & $\begin{array}{c}\text { Public } \\
\text { Private } \\
\text { Academia } \\
\text { Civic Society }\end{array}$ & $\begin{array}{c}\text { Public } \\
\text { Private } \\
\text { Academia } \\
\text { Civic Society } \\
\text { Social Entrepreneurs or/and Activists }\end{array}$ \\
\hline Citizenship Response & Invisible and Passive & Reactive and Passive & Proactive \\
\hline Governance Scheme & Technocratic Top-Down & Institutionalised Bottom-Up & Emergent/Democratised Bottom-Up \\
\hline
\end{tabular}




\subsection{Resulting Business/Social Models in Smart Cities}

In order to operationalise the multistakeholder framework analysis, the conducted research in the three Replicate follower cities-which allow for identifying the strategic priorities by a selected number of strategic stakeholders in each city-links up the composition of stakeholders with the resulting business/social models.

This article defines business/social models as the resulting and collective preferences made by the strategic stakeholders-selected by the city representative- of how a city should create economic and social value collectively through the development of urban innovative services that are technically feasible and democratically desirable, while reducing the city's overall environmental footprint. This research acknowledges, though a potential uncertain precondition and ideological bias exist, that a democratic smart city can only be built as long as the strategic stakeholders selected by the city representative in charge of coordinating the smart city strategic formulation are democratically nominated with enough public scrutiny and transparency.

This article operationalises five business/social models (Table 2) stemming from the literature review of the multistakeholder helix policy framework analysis (Table 1). Yet, these classifications (Table 1 on helixes and Table 2 on models, respectively) are neither prescriptive, normative, nor deterministic in essence; instead, these typologies co-exist with each other within a single city's urban environmental strategy [82]. The potential of these business/social model typologies is to present their evolution by reaching (and thus testing) the widest version (the penta-helix framework) comparatively in three European cities. This premise is a methodological position rather than a normative prescription: amid the penta-helix framework, several business/social models can co-exist in smart city sectors (energy, mobility, and ICT; 5th Strategic Dimension) in different cities, as it will be observed in the fourth section of this article.

Despite the methodology employed to compare and analyse the multistakeholder composition in each city, three relevant caveats should be made before discussing each business/social model: (i) first, these business/social models were offered to a group of strategic stakeholders (representing a diverse set of helixes) in each city as suggestions for their strategic preferences; (ii) second-and this caveat is the core aspect of the fieldwork research conducted—each stakeholder prioritised strategic preferences per item presented; and (iii) ultimately, and more importantly, the business/social model resulted in a collective outcome made by the entire representation of stakeholders. Thus, the results presented in the fourth section refer to a triangulation methodology based on 25 in-depth interviews with strategic stakeholders in each city. These interviews were processed collectively through a validation workshop thereafter, while being contrasted with appropriate desk research throughout the whole data collection process. Moreover, as it will be observed, the plurality of options was visible in all cases of the three cities.

The first model proposed is the Direct Public Provision (DPP). This model is the most straightforward for organising services. For stakeholders, the model can be beneficial in terms of democratic accountability. Under this model, there is a direct link of responsibility between the local government and administration, and their citizens for the design to deploy the service [27]. This approach can help, although not guarantee, that citizens' voices will be considered. By establishing its own priorities and working directly with citizens, the municipality can ensure that social interests are not lost to concentrated special and monopolistic interests in the transition to a smart city. Yet, the challenges of DPP are related to the financial element of the city management model. Budget restrictions across Europe, especially in southern countries, have made it more difficult for governments to allocate funds to new smart services [113]. Involving external stakeholders, from private firms to service users and their communities, in the production of smart services can alleviate some of the financial burdens. The service provision with external stakeholders also tends to a have greater innovation capacity than direct delivery because of the wider range of ideas and experience they provide [114]. There is a clear downside of DPP in this regard, however, as some cities might face more difficulties than others when directly financing services. 
The second model for service provision that this article suggests is the so-called PPP. Forrer et al. [27] (p. 476) define PPP as "an ongoing agreement between the government and private sector organisations in which the private organisation participates in the decision-making and production of a public good or service that has traditionally been provided by the public sector and in which the private sector shares the risk of that production." This definition may differ from the interpretation made by Mazzucato [32], who debunked PPP myths. Mazzucato is regarded as one of the most influential modern economists and argues that the public sector should not only be perceived as a passive corrector of market failure, but also as an entrepreneurial partner with a broader range of roles in stimulating innovation. Further, Forrer et al.'s definition might be problematic after the fieldwork action research conducted in the three case studies. The penta-helix somehow makes explicit the critique related to unforeseen negative social impacts when PPP does not even engage citizens or peripheral stakeholders in the smart city strategic formulation $[43,115]$. Therefore, the third and fourth models are variations of the PPP: triple-helix by including academia, and quadruple-helix by adding civic society to the triple-helix. The third model is called the Public-Private-Academic Partnership (PPAP), and the fourth model is called the Public-Private-Academic-People Partnership (4PA).

The PPAP model, as an evolution of the traditional PPP, encourages academic partners not only to participate in the delivery of services, but also to benefit from the active learning process while the public and private partners benefit from harnessing the research capacity of the university [116]. PPAP essentially resonates with the triple-helix multistakeholder framework (Table 2). PPAP can offer increased innovation capacity because universities' nonprofit orientation and emphasis on knowledge provide them the ability to explore new ideas that might not be commercially viable yet, but might eventually be profitable [117]. This model is particularly appropriate for large-scale projects that tend to involve several governments and consortia of private and academic partners [95]. Further, the model most likely applies to the ICT sector and smart cities, and particularly to projects like developing an ICT infrastructure and integrated service platforms for firms and users [17]. The advantage of the PPAP model is that, by including a larger variety of stakeholders around academia, they might be more likely to achieve the social acceptability dimension, albeit far from democratic requirements, such as cases when there is open engagement with communities outside the scientific or business community, which is not always the common trend. As such, PPAP can otherwise create asymmetric power relations in which citizens and their communities are either not given any opportunities to participate in developing scientific solutions (but will, nonetheless, often provide their data) or are only given the opportunity to provide feedback in an informative fashion at the end of the project, but not throughout [118]. Such power relations, in turn, can result in scientific solutions that will not be adopted by citizens or stakeholders for being too far removed from their real needs.

A way to address the previous challenge could be through maximising citizens' engagement in the design and delivery of the service provision. This approach is the fourth model called 4PA, which essentially resonates with the quadruple-helix multistakeholder framework (Table 2). 4PA emerges in response to some of the challenges inherent to the traditional PPP model, including the accountability challenges discussed above. Specifically, PPP has been critiqued for developing a framework of service or project delivery that overlooks the interests and views of the general public [119]. The 4PA model, in contrast, aims to provide a framework in which mechanisms to aggregate social concerns are embedded at different stages of the development and delivery process. The civic society domain overseeing a particular project can, therefore, create opportunities for citizens or particular stakeholders around the societal challenge to open up an informative process by providing feedback or getting involved in the project conception and deployment. In smart cities, people living in districts are clearly these strategic stakeholders whose engagement is crucial for the success of the intervention that "should be exposed to societal deliberation at an earlier stage in their development" [120] (p. 1). However, this model is not a panacea for smart cities insofar as conflicts arise if decision-making processes and deliberation are not accurately prepared with the necessary attention and with mediators and ambassadors to curate the whole process without influencing it excessively and directly. 
Table 2. Literature Review: Resulting Business/Social Models in Smart Cities.

\begin{tabular}{|c|c|c|c|c|c|}
\hline & \multicolumn{5}{|c|}{ Resulting Business/Social Models in Smart Cities } \\
\hline & Direct Public Provision (DPP) & $\begin{array}{l}\text { Public-Private Partnerships } \\
\text { (PPP) }\end{array}$ & $\begin{array}{l}\text { Public-Private-Academic Partnerships } \\
\text { (PPAP) }\end{array}$ & $\begin{array}{l}\text { Public-Private-Academic-People Partnerships } \\
\text { (4PA) }\end{array}$ & $\begin{array}{l}\text { Urban/Data Commons } \\
\text { (U/DC) }\end{array}$ \\
\hline Literature Review & {$[27,113,114]$} & {$[27,32,43,115]$} & {$[17,116-118]$} & [119] & {$[14,18,34,47-52,60,63,78,121-128]$} \\
\hline Helix framework & Mono-helix & Double-helix & Triple-helix & Quadruple-helix & Penta-helix \\
\hline Stakeholders & - Public & $\begin{array}{ll}\text { - } & \text { Public } \\
\text { - } & \text { Private }\end{array}$ & $\begin{array}{ll}\text { - } & \text { Public } \\
\text { - } & \text { Private } \\
& \text { Academia }\end{array}$ & $\begin{array}{ll}\text { - } & \text { Public } \\
\text { - } & \text { Private } \\
\text { - } & \text { Academia } \\
& \text { Civic Society }\end{array}$ & $\begin{array}{ll}\text { - } & \text { Public } \\
\text { - } & \text { Private } \\
\text { - } & \text { Academia } \\
\text { - } & \text { Civic Society } \\
& \text { orcial Entrepreneurs } \\
& \text { or/and Activists }\end{array}$ \\
\hline Executive Summary & $\begin{array}{ll}\text { - } & \text { Straightforward } \\
\text { - } & \text { Democratic accountability } \\
\quad \text { Budget restrictions }\end{array}$ & $\begin{array}{l}\text { - Private sector participating in } \\
\text { the decision-making and } \\
\text { production processes } \\
\text { Debunk PPP myths } \\
\text { - Other stakeholders excluded }\end{array}$ & $\begin{array}{l}\text { - University benefits from the } \\
\text { learning process } \\
\text { - } \quad \text { Large-scale projects fit into this } \\
\text { suitable model } \\
\text { - }\end{array}$ & $\begin{array}{l}\text { - Social concerns at different stages } \\
\text { District level interventions fit into this } \\
\text { suitable model }\end{array}$ & $\begin{array}{l}\text { May include the communal } \\
\text { ownership of the outcome } \\
\text { - Stakeholders the source } \\
\text { of innovation } \\
\text { To ensure inter-stakeholder } \\
\text { consensus/conflicts }\end{array}$ \\
\hline
\end{tabular}


By this sequence, this article reaches the fifth and the last model, Urban/Data Commons (U/DC), in which the fifth helix may emerge consciously or unwittingly through the interactions between stakeholders and aggregates the necessary agency [34] to facilitate intermediation conditions among them [63]. This model has more direct citizen and stakeholder engagement (than previous PPAP and 4PA), also known as co-creation or co-production. Stakeholder engagement is defined as "the active involvement of end-users and their communities in the various stages of the public service provision" [121] (p. 1335). However, the concept of the commons (both urban and/or data) includes the ownership of the outcome beyond the co-created or co-produced involvement of stakeholders in the decision-making process [122]. Thus, this fifth model essentially resonates with the penta-helix multistakeholder framework (Table 2), focusing not only on the delivery side of public services and the initial design process, but also on the ownership of such outcomes being delivered $[115,123,124]$. Moreover, this model differentiates itself from the 4PA model in how it implies a direct two-way reciprocal relationship between stakeholders involved in representing the entire range of helixes. While one best practice of this could be the project developed by the Barcelona City Council called 'Decidim' [51,125], by contrast, the absence of any attempt to set up a multistakeholder policy framework could be clearly spotted in the so-called case of Toronto, Sidewalk Labs, with critics arguing that this project subverts democracy owing to the monolithic power owned by Google's parent big-tech firm Alphabet. This situation raises questions, in the absence of an alternative data commons model, about who will own the smart city's infrastructures and platforms and who will control the access to their services through data ecosystems [14,18,78,115,126].

This fifth business/social model U/DC serves two important purposes. First, individuals represented through any stakeholder helix can be a source of innovation in the production of city-making because they contribute unique experiential knowledge of the service that can lead to significant improvements. Second, this model ensures that the consensus and conflicts of inter-stakeholders are deeply treated by considering antagonist interests [60], confronted concerns of users, and the whole democratic dimension of the community-building where citizens' ownership of the new services embraces the paradigm of the (urban) commons [127,128]. Particularly, data commons become a sensitive issue insofar as the digital data could be used to monitor and track citizens with or without their consent. Thus, smart city interventions that involve the collection and analysis of data also strongly rely on citizens' decisions. Since it is citizens' data that will be collected, cities are facing pressures to actively engage citizens in their data policy and strategies [51,83].

\section{Methodology: Mapping Out the Penta-Helix Multistakeholder Policy Framework}

This empirical research compared the multistakeholder policy framework in three follower cities of the project EU-H2020-SCC-Replicate by employing the penta-helix policy framework. By doing so, the examination was focused on five strategic dimensions-three on multistakeholder frameworks and two on resulting business/social models-studied through intensive action research fieldwork conducted from February 2017 to December 2018 in the three cities. The research revealed key qualitative observations and mapped out evidence-based empirical results on the five strategic dimensions studied in each follower city: (i) the composition of stakeholders per helix; (ii) the most influential stakeholder-helix; (iii) the most proactive stakeholder-helix; (iv) knowledge on the PPP; and ultimately, (v) the most suitable business/social model (per smart city sector too) in each follower city. The results were obtained in each city comparatively for the three Replicate follower cities (www.replicate-project.eu/city2citylearning) based on in-depth interviews with a selected group of 25 strategic stakeholders representing the penta-helix framework through in-depth interviews and later validated later through a workshop (Table A1 in the Appendix A section) [54]. The five strategic dimensions inferred from the literature review and the results of the empirical research were used to build the comparative methodology of the three cases, which addresses the research questions of this article, presented in the Introduction section. 


\subsection{Action Research Fieldwork}

The methodology used to apply the penta-helix policy framework included fieldwork research based on action research. Action research encompasses seven features [129]: (i) it stems from SI, which is a significant multidisciplinary approach blending scientific research, business administration, public debate, and ethical controversy [130]; (ii) it unfolds socio-cultural meanings in given territorial contexts through ethnographic fieldwork research; (iii) it aims at generating practical action for stakeholders' betterment; (iv) it is based on participatory research processes that are inclusive of plural ways of knowing in the constitution of theory and practice; (v) it is iterative and heuristic, a continual process of evolving inquiry and action, by learning from reflections on successes and failures; (vi) it is conducted by participants/stakeholders for participants/stakeholders, which addresses the fundamental questions of research; and ultimately, (vii) it is based on democratic ethos, which aims to critique power relations, address grievances of marginalised groups, and achieve smart city-regional empowerment in the face of entrenched institutionalised power.

\subsection{Research Design: Triangulation}

The research design was based on the mixed-method technique of triangulation via action research (Figure 2), which encompassed (i) desk research (summarised through Tables 1 and 2 on the conducted literature reviews), (ii) the findings of 75 in-depth interviews with strategic stakeholders selected by the city representative in each city following the penta-helix framework, and (iii) results corroborated through three validation workshops, one per each case study city. Comparative case study research, as defined by Yin [131], was identified as the most effective form of mixed-method research. This mixed-method process refers to the practical work conducted by the author to gather evidence-based data through in-depth interviews and validation workshops. The sample consisted of strategic stakeholders selected by the city representative according to his/her criterion-data is anonymised in this article to comply with the GDPR and the University of Oxford ethical procedures for informed consent in fieldwork research (Table A1 in the Appendix A section)_aiming to accomplish certain methodological foundations to ensure a minimum degree of representation in the sample.

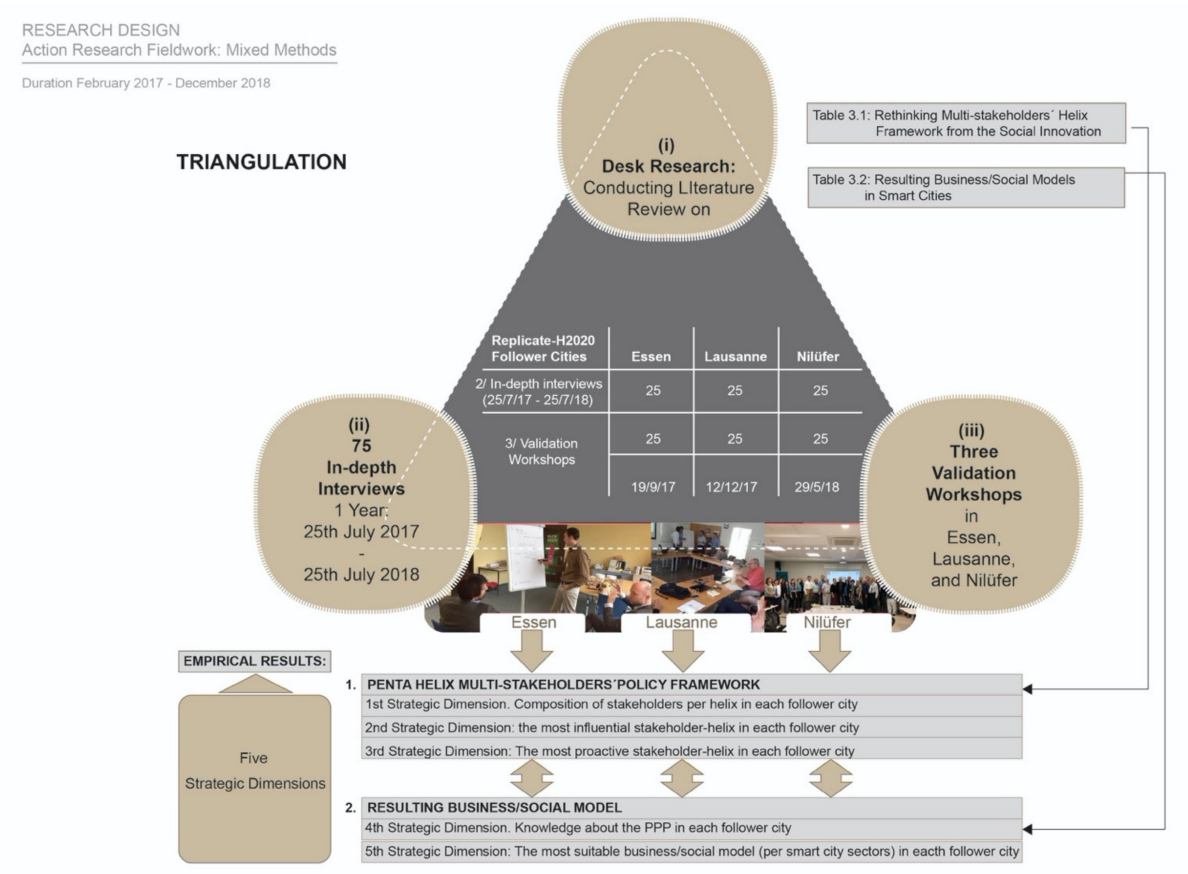

Figure 2. Methodology: Research design based on the mixed-method technique of triangulation via action research. 


\subsection{Data Collection and Analysis}

Data collection through action research was arranged iteratively and paralleled two streams of research while conducting desk research: on one hand, in-depth interviews for the three follower cities occurred from 25 July 2017 to 25 July 2018. On the other hand, in each follower city, a validation workshop was conducted on the following dates: 19 September 2017 in Essen, 12 December 2017 in Lausanne, and 29 May 2018 in Nilüfer.

\subsubsection{In-Depth Interviews}

Owing to the language barriers of many stakeholders in the three follower cities, a semistructured 15-question questionnaire in English was designed from February 2017 to July 2017 (Table A2 in the Appendix A section). The data collection started on 25 July 2017 via in-depth interviews being conducted in parallel in the three cities for one year; data collection ended on 25 July 2018, once 25 strategic stakeholders were interviewed in each city. The list of interviewees was meticulously designed and reviewed by each city representative to ensure that the widest level of plurality was reached in their cities. The strategic stakeholders answered the questionnaire; they were encouraged to validate and revise their earlier responses in light of the answers of other members of their validation workshop.

\subsubsection{Validation Workshops}

During the fieldwork research process, three validation workshops (one per follower city) were scheduled at different intervals of the data collection. The validation workshops, which ensured that the data collected were not biased or wrongly received, consisted of a selection of 5 five questions (from the semistructured questionnaire).

It was demonstrated that during this process, disagreement and conflict were shown among a diverse set of stakeholders. The validation workshop collected these tensions and confrontational dynamics. The role played by the social entrepreneurs/activists as intermediators in the three cities (C RING, Impact Hub Ruhr, and Camp Essen in Essen, Germany; Eqlosion, in Lausanne, Switzerland; and Teracy, Mendireck, and Demir Energy facilitators in Nilüfer) was remarkable during this validation process. The final scores stemming from the sum of the in-depth interviews were tabulated depending on the discussion and the re-arrangement suggested among stakeholders. Again, within this validation process, the role played in clarifying the discussion by those stakeholders who self-identified as fifth helix was substantial to determine the empirical results presented in Table 3. The fieldwork fixed 25 responses from strategic stakeholders in each follower city as the average threshold to obtain.

The following subsection briefly presents the profile of the three follower cities and the general composition of stakeholders in each city structured by the penta-helix framework [52].

\subsection{Comparing Three Case Studies: Follower City Profile}

REPLICATE (REnaissance of PLaces with Innovative Citizenship And TEchnologies) is the name of the European research and development project that aims to deploy integrated energy, mobility, and ICT solutions in city districts. The project has a consortium encompassing 38 partners. There are three lead cities (called lighthouses): San Sebastian (Spain), Florence (Italy), and Bristol (UK) (Figure 3). The case studies of this article encompassed the cities called followers that aimed to look into replicating interventions in their cities: Essen (Germany), Lausanne (Switzerland), and Nilüfer (Turkey).

The City of Essen is located in the North Rhine-Westphalia in the heart of the Ruhr Area, which encompasses approximately 5.1 million people. Following London and Paris, this metropolitan area constitutes the third largest urban agglomeration in Europe. Essen is an independent city in the administrative district of Düsseldorf, and its 582,624 inhabitants make it the ninth largest city in Germany. Essen has made a transition from a coal and steel metropolis to a European Green Capital. The municipal area of $210 \mathrm{~km}$ per square is divided into 9 districts and 50 neighbourhoods. Further, 
Essen is an important industrial centre for German enterprises and private foundations (E. ON SE, Stiftung Mercator, and Westnetz $\mathrm{GmbH}$ ). E. ON SE is an electric utility private company based in Essen, North Rhine-Westphalia, and it runs one of the world's largest investor-owned electric utility science providers. Stiftung Mercator is a private and independent foundation promoting science, education, and international understanding. And Westnetz $\mathrm{GmbH}$ is a private company that serves as an electricity and gas distribution network operator from its headquarters located in Dortmund beyond the North Rhine-Westphalia city-region. A combination of big firms, SMEs, and an active craft sector maintains a good economic climate. The composition of stakeholders and their strategic preferences resonate with a new and emerging start-up scene integrally involved in mediating among organisations and projects in Essen (Germany) (Camp-Essen, Impact Hub Ruhr, and Essen 51, among others) [132]. The European Green Capital 2017 project shares a very comprehensive relationship with Essen's goal to establish a smart city strategy.
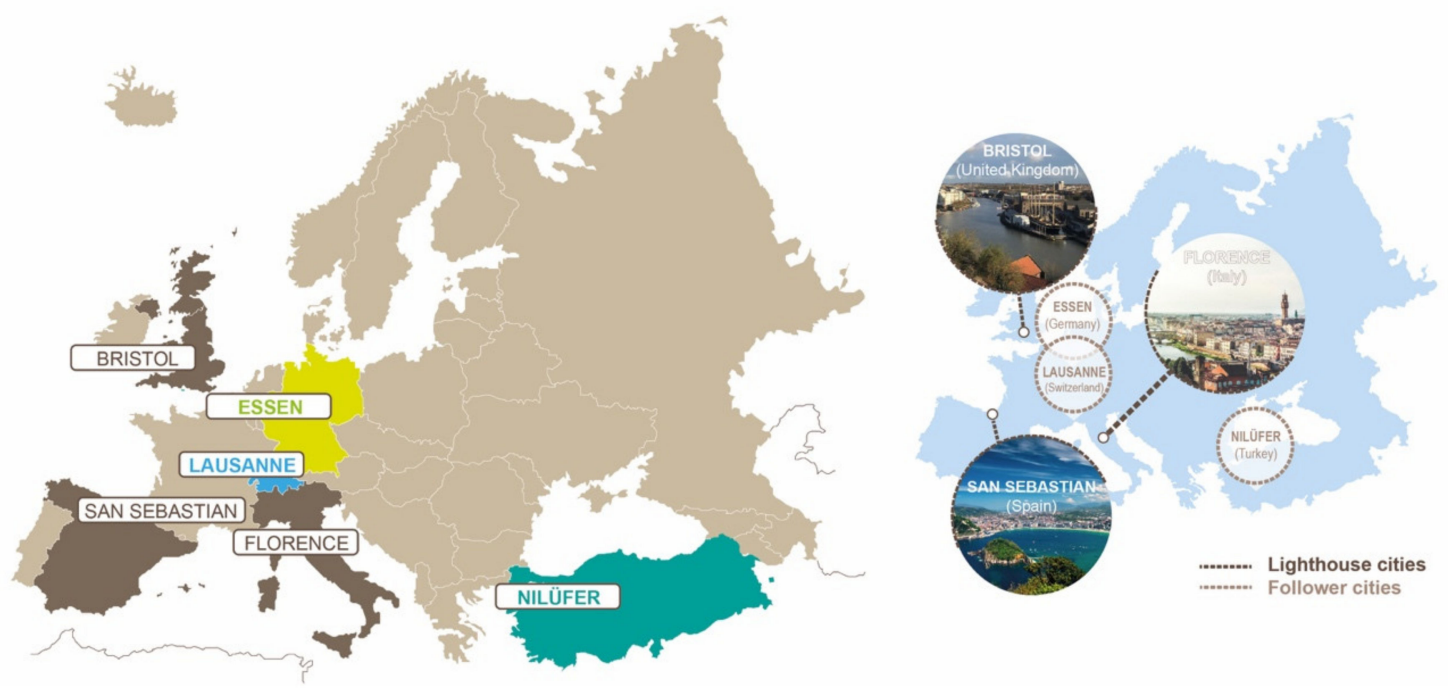

Figure 3. Replicate EU-H2020-SCC project cities: Lighthouses (San Sebastian, Bristol, and Florence) and Followers (Essen, Lausanne, and Nilüfer). Source: https://replicate-project.eu/city2citylearning/ [54].

During the fieldwork action research process for validation, stakeholders in Essen showed a high level of interaction, particularly by the three stakeholders representing the fifth helix. The level of overlap between academia, the private sector, and social entrepreneurs/activists was high as it was depicted by the strategic project that requires the involvement of several stakeholders having a wide vision of the city (Figure 4).

Lausanne is the fourth biggest city in Switzerland. It consists of 142,000 inhabitants and is the centre of an urban area with 350,000 inhabitants. Lausanne's main firms are Innobridge Service Sàrl, Tetra Pak, and Logitech. In addition to them, it is worth considering the importance of companies such as AGEN, CFT, and Landolt, among others. In 2016, Lausanne launched an energy efficiency programme called Equiwatt, with the objective of saving energy for individuals and businesses, thereby raising awareness regarding energy consumption. In the mobility sector, Lausanne has been striving for many years to limit the overwhelming space taken up by private cars to encourage more access to shops and businesses. By reducing authorised parking times on the streets, the municipality encourages commuters to leave their vehicles at outlying Park \& Ride facilities. The private car traffic has been reduced by 6000 vehicles per day. Further, the city stakeholders have been working towards an eco-district called Plaines du Loup, which attempts to promote a public transport axis, a heat production innovative concept based on deep geothermal and heat recovery from wastewater. Strategically speaking, though, ICT seems to be a pending subject for Lausanne [133]. 


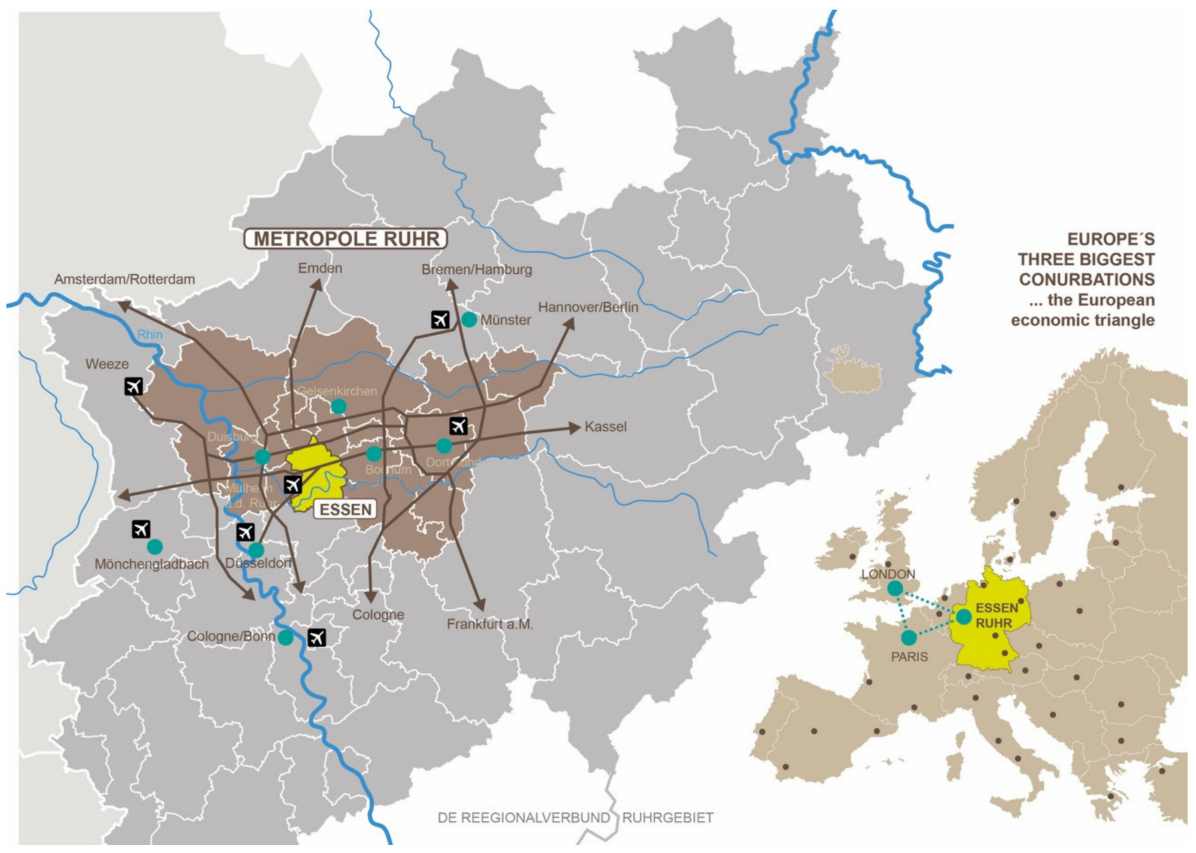

Figure 4. Essen, follower city. Source: https://replicate-project.eu/city2citylearning/ [54].

During the fieldwork action research process for validation, the stakeholders' interaction was clearly dominated by the public sector insofar as it is responsible for the flagship project called Plaines du Loup. However, beyond the widely approved project, clear disagreement existed among stakeholders in terms of how to implement the given project, which demonstrated a need to keep opening a democratic consultation channel intermediated by the fifth helix represented by Eqlosion (Figure 5).

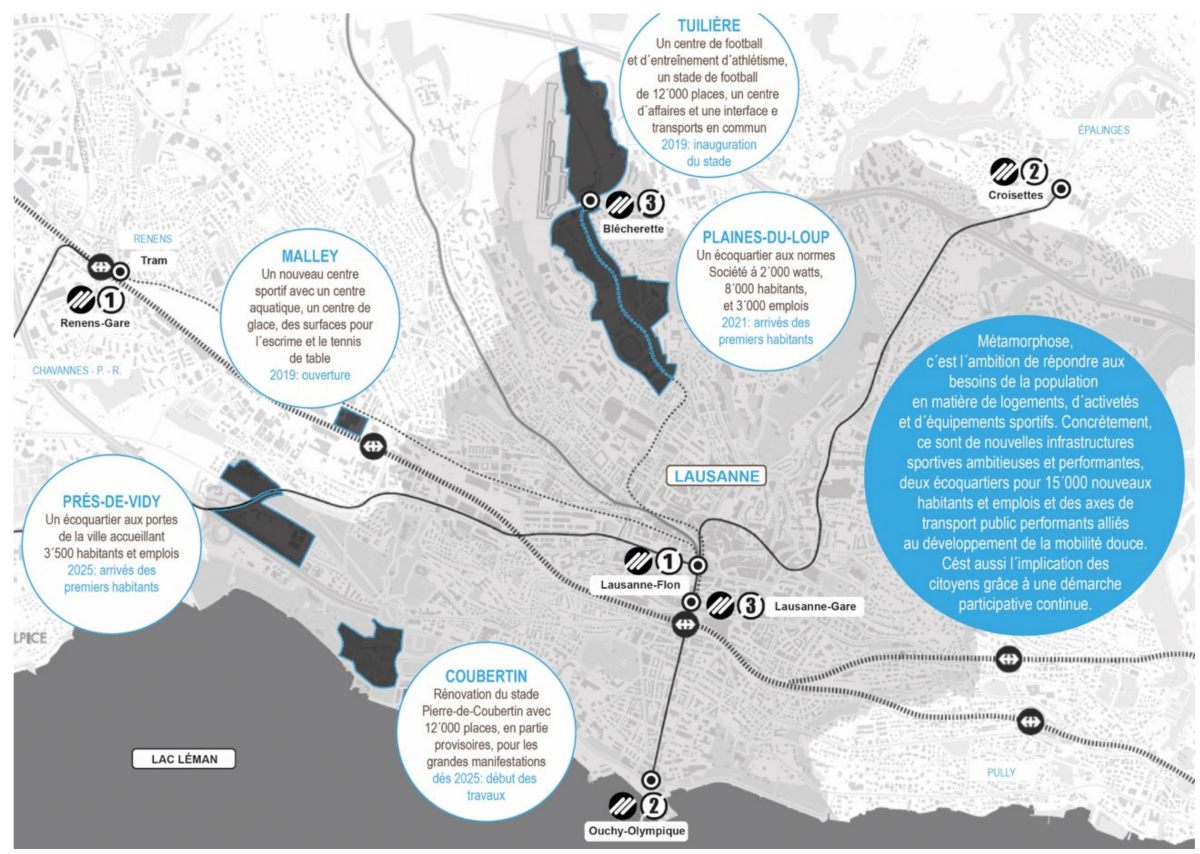

Figure 5. Lausanne, follower city. Source: https://replicate-project.eu/city2citylearning/ [54].

Nilüfer is one of the 17 districts of Bursa Province. Providing logistics connections for major cities, such as Ankara, İstanbul, and İzmir. Bursa enjoys a key geographic location in Turkey: it is 
in close proximity to national and global markets. There are three universities offering world-class education. Advanced infrastructure, dynamic entrepreneurs, and a high quality of life and work create an attractive investment and social climate. Moreover, Nilüfer has been established as the main residential development area of Bursa to meet housing needs of not only the growing city, but also industrial and commercial structures. Nilüfer comes first among the districts of Bursa in terms of the economic contributions while providing employment opportunities to $80 \%$ of the Bursa population via the Organized Industrial Zones within its border. The population increase in the last five years was $35 \%$. This growth is higher than the average of Turkey and Bursa and will probably continue, owing to the attraction of the city to industrial investment and, thus, the availability of jobs. The population of Nilüfer encompasses $13.98 \%$ of the total population of Bursa $(2,842,547)$. Bursa is viewed as one of the fast-growing middle-weight provinces projected to account for more than $60 \%$ of global GDP growth over the next 15 years. There are 16 organised industrial zones and a free-trade zone with clusters in automotive, textile, machinery, food, and furniture. The multistakeholder framework focused on grassroots empowerment through neighbourhood committees and energy co-operatives. The private sector is leading a strong transformation through industry 4.0 and spin-off ecologies [134].

During the fieldwork action research process for validation, the level of participation was remarkably outstanding, which showed the strong deliberative ethos that the city possesses. Particularly, the role played by social entrepreneurs/activists (including Teracity, Mendirek, and Demir Energi facilitation intermediaries) was crucial to spark and guide a constructive debate, particularly when the debate around the understanding of PPP arose in Nilüfer (Turkey) (Figure 6).

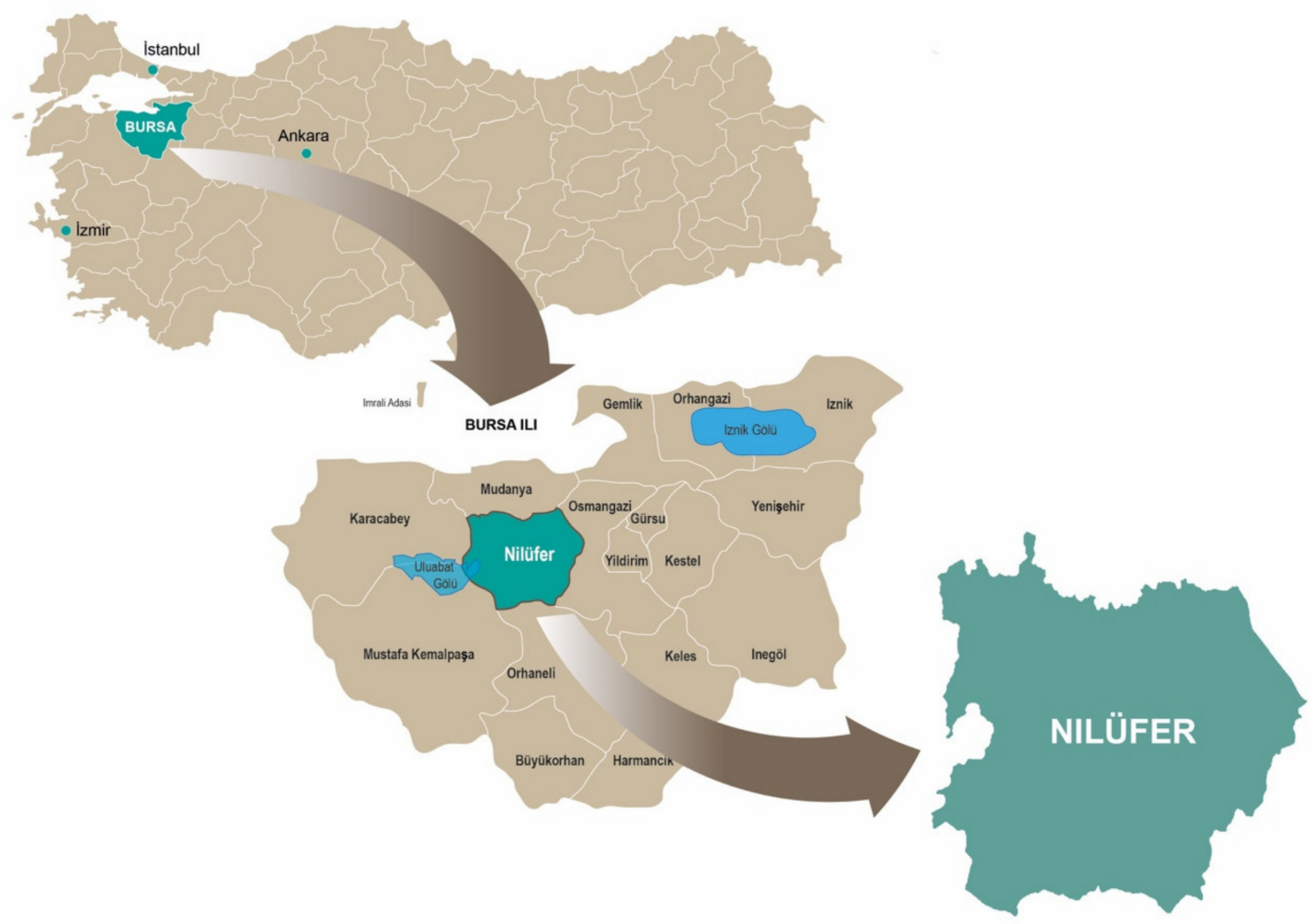

Figure 6. Nilüfer, follower city. Source: https://replicate-project.eu/city2citylearning/ [54].

\section{Results, Discussion, and Analysis: Comparing Three Follower Cities in H2020-SCC- Replicate Project}

This article argues that applying the penta-helix multistakeholder framework, albeit adapted to the unique context of urban governance, can support the city councils of the follower cities to manage their own update transitions towards a more democratic smart city approach. The penta-helix 
framework is intimately connected with the logic of the city business/social models insofar as it provides an understanding of the stakeholder composition while essentially serving as a policy tool for city governments to articulate the smart city strategy.

To operationalise the penta-helix, the fieldwork action research was conducted by triangulating desk research, in-depth interviews, and validation workshops (Figure 2), assisted by a questionnaire encompassing five strategic dimensions (Appendix A, Table A2).

\subsection{Five Strategic Dimensions}

The penta-helix framework was conducted by systematising five strategic dimensions through the questionnaire in which each person individually responded to and later validated collectively the following aspects: (i) which helix each stakeholder belonged to (composition), (ii) which was the most influential helix (influence), and (iii) which was the most proactive helix (proactivity). Moreover, regarding the suitability of the resulting business/social models (DPP, PPP, PPAP, 4PA, and U/DC), each person responded to (iv) whether the person knew the meaning of PPP and (v) which business/model was the most suitable in general and as per the smart sector (energy, mobility, and ICT) (Table 3).

Table 3. Empirical results.

1. Penta-Helix Multistakeholder Policy Framework

\begin{tabular}{|c|c|c|c|c|c|}
\hline & $\%$ & Essen & Lausanne & Nilüfer & Global \\
\hline \multicolumn{6}{|c|}{ 1st Strategic Dimension: Composition } \\
\hline 1. & Public & 52 & 36 & 20 & 36 \\
\hline 2. & Private & 12 & 12 & 32 & 18 \\
\hline 3. & Academia & 16 & 24 & 20 & 20 \\
\hline 4. & Civic society & 8 & 16 & 12 & 12 \\
\hline 5. & Social E/A & 12 & 12 & 16 & 14 \\
\hline & TOTAL & 100 & 100 & 100 & 100 \\
\hline \multicolumn{6}{|c|}{ 2nd Strategic Dimension: Influence } \\
\hline 1. & Public & 28 & 80 & 44 & 50 \\
\hline 2. & Private & 44 & 12 & 28 & 28 \\
\hline 3. & Academia & 8 & 0 & 12 & 7 \\
\hline 4. & Civic society & 0 & 8 & 16 & 8 \\
\hline 5. & Social E/A & 20 & 0 & 0 & 7 \\
\hline & TOTAL & 100 & 100 & 100 & 100 \\
\hline \multicolumn{6}{|c|}{ 3rd Strategic Dimension: Proactivity } \\
\hline 1. & Public & 16 & 21 & 24 & 20 \\
\hline 2. & Private & 21 & 22 & 23 & 22 \\
\hline 3. & Academia & 21 & 21 & 16 & 19 \\
\hline 4. & Civic society & 22 & 16 & 21 & 20 \\
\hline 5. & Social E/A & 19 & 20 & 16 & 19 \\
\hline & Total & 100 & 100 & 100 & 100 \\
\hline
\end{tabular}


Table 3. Cont

1. Penta-Helix Multistakeholder Policy Framework

\begin{tabular}{|c|c|c|c|c|c|}
\hline & $\%$ & Essen & Lausanne & Nilüfer & Global \\
\hline 2. & \multicolumn{5}{|c|}{ Resulting Business/Social Model } \\
\hline \multicolumn{6}{|c|}{ 4th Strategic Dimension: Knowledge about PPP } \\
\hline 1. & Yes & 92 & 60 & 76 & 76 \\
\hline 2. & Maybe & 4 & 40 & 12 & 20 \\
\hline 3. & No & 4 & 0 & 12 & 4 \\
\hline & Total & 100 & 100 & 100 & 100 \\
\hline \multicolumn{6}{|c|}{ 5th Strategic Dimension: Business/Social Models Suitability } \\
\hline 1. & DPP & 18 & 17 & 15 & 17 \\
\hline 2. & PPP & 21 & 23 & 21 & 22 \\
\hline 3. & PPAP & 20 & 23 & 21 & 21 \\
\hline 4. & $4 \mathrm{PA}$ & 19 & 19 & 21 & 19 \\
\hline 5. & U/DC & 22 & 18 & 22 & 21 \\
\hline & Total & 100 & 100 & 100 & 100 \\
\hline \multicolumn{6}{|c|}{ Energy } \\
\hline 1. & DPP & 12 & 34 & 16 & 21 \\
\hline 2. & PPP & 36 & 6 & 28 & 23 \\
\hline 3. & PPAP & 16 & 20 & 40 & 25 \\
\hline 4. & $4 \mathrm{PA}$ & 20 & 20 & 4 & 15 \\
\hline 5. & U/DC & 16 & 20 & 12 & 16 \\
\hline & Total & 100 & 100 & 100 & 100 \\
\hline \multicolumn{6}{|c|}{ Mobility } \\
\hline 1. & DPP & 24 & 20 & 20 & 21 \\
\hline 2. & PPP & 24 & 34 & 28 & 29 \\
\hline 3. & PPAP & 4 & 13 & 16 & 11 \\
\hline 4. & $4 \mathrm{PA}$ & 28 & 20 & 16 & 21 \\
\hline 5. & $\mathrm{U} / \mathrm{DC}$ & 20 & 13 & 20 & 18 \\
\hline & Total & 100 & 100 & 100 & 100 \\
\hline \multicolumn{6}{|c|}{$\mathrm{ICT}$} \\
\hline 1. & DPP & 8 & 20 & 0 & 9 \\
\hline 2. & PPP & 28 & 27 & 27 & 28 \\
\hline 3. & PPAP & 24 & 27 & 52 & 34 \\
\hline 4. & $4 \mathrm{PA}$ & 8 & 13 & 13 & 11 \\
\hline 5. & U/DC & 32 & 13 & 8 & 18 \\
\hline & Total & 100 & 100 & 100 & 100 \\
\hline
\end{tabular}

\subsection{Empirical Results}

Regarding the first strategic dimension, amid the global picture of the three follower cities, the most represented helix was the public sector. However, it is remarkable that the profiles of stakeholders following this hegemonic helix, respectively, are academia, the private sector, social 
entrepreneurs and activists, and civic society. Strikingly, though, the composition in the three follower cities varies considerably: while Essen and Lausanne (with a strong academic presence) were highly represented by people from the public sector, Nilüfer was represented by the private sector, owing to the great interest in developing a new economic model for the metropolitan area as a consequence of the demographic boost. However, in the three cases, it could be highlighted the regular presence of stakeholders representing the fifth helix, which this article refers to as intermediaries (the detailed classification is shown in Table A1 in the Appendix A section).

Examining the second strategic dimension, the fieldwork enquired about the most influential helix and found that, globally, the public sector still overcomes the private influence. However, from case to case, the most influential helix varies: Lausanne overwhelmingly (and consistently with its current publicly owned flagship district intervention, Plaines du Loup) selected the public sector and underscored academia as the most represented helix in the composition of its framework, which entirely contrasts the results obtained in the other two follower cities. In Essen, the strategic alliance between the private and the social entrepreneurial/activist appears to be the most influential helix with strong public support. On the other hand, in Nilüfer, owing to the institutional boundaries and politically fragile situation, the triad between the public-private-civic society still appears to influence the multistakeholder policy framework.

The third strategic dimension related to the level of proactivity in each helix per city illustrates a rather regular picture with almost similar distribution in each city per helix (between 16-24\%). In line with the rationale of this article, the fifth helix reveals itself as part of the ecosystem of proactive stakeholders in the three follower cities. Case by case, in Essen, it seems inspiring and hopeful that the leading proactive role of the civic society contrasts with the low level of influence provided to this helix. Similarly, in Lausanne, the proactivity level observed in the private sector differs from the low level of influence regarding this helix. Ultimately, in Nilüfer, the public sector seems to be leading in both its level of influence and proactivity.

After examining the three strategic dimensions related to the multistakeholder framework regarding composition, influence, and proactivity, the fieldwork focused on the resulting business/social models. Notably, the fourth dimension asking about the understanding of the PPP sparked a deep discussion in the validation workshops of the three follower cities, which in itself demonstrates the openness of stakeholders in the three cities to go beyond, or at least question, the internal arrangements of the PPP. Furthermore, responding to the two intertwined research questions of this article, the debate in the validation workshop invited further exploration of how SI can occur through intermediating smart city initiatives among stakeholders by establishing ad hoc business/social models. This aspect was responded to operationally through the fifth strategic dimension.

The fourth strategic dimension entirely focused on the knowledge of PPP. Despite the expected affirmative answer being a generic answer, the level of debate in the validation workshops among stakeholders, particularly in Lausanne and Nilüfer, explains and illustrates the doubts, as many responded with Maybe and directly with No: while $40 \%$ in Lausanne responded with Maybe, and $12 \%$ in Nilüfer opted for No. These findings clearly reveal that PPP could have entirely different interpretations and positions, which contrast the idea of it being the only business/social model in the multistakeholder framework, as this article elucidates.

Ultimately, the fifth strategic dimension depicts an interesting comparative result for each city, despite that the most suitable model (not the only one, though), generically speaking, was the PPP. Lausanne predominantly and collectively selected PPP and PPAP, but Essen and Nilüfer appeared to show an experimental strategic willingness when selecting U/DC. A reason that could explain these results is the openness and willingness for a further experimental approach, insofar as cities seemed to embrace further complex business/social models that result in interdependencies among stakeholders and the related decision-making processes. From the current DPP in Lausanne, stakeholders clearly and collectively pointed out PPP and PPAP as a suitable step forward. In the case of Essen, the alliance between the private sector and the entrepreneurial ecosystem presumably derives to a model with 
intermediaries, bricoleurs, assemblers, and brokers for transforming the regional economic model as a whole, supported by a strong public sector. Finally, Nilüfer, being dependent on the current DPP model but with resilient leadership in the public sector, may be keen to further explore PPP, PPAP, and even 4PA by gradually including social innovators in their transformational processes, as is the case with the strategic endeavour of the city council of Nilüfer to establish the Centre for Social Innovation. More detailed information about the stakeholders in each city can be found in the Appendix A, Table A1.

However, the suitability of business/social models clearly differs from city to city when focusing on specific sectors, which clearly validates the rationale of this article suggesting going beyond the PPP hegemonic model. The debate on the validation workshop was conducted through specific initiatives and projects related to ongoing implementations in the energy, mobility, and ICT sectors. The detailed analysis of such interventions goes beyond the scope of this article. Nonetheless, the emergency of a plethora of actions subject to be openly discussed among a wide range of stakeholders clearly indicates the potential of the variation of such models for a democratic deliberation in smart cities.

As such, starting with energy, follower cities selected their current position as the most suitable one. In Lausanne, the model on DPP for the district heating fits consistently with the flagship project Plaines du Loup and apparently well into the expectations of the stakeholders. In Essen, PPP appears to work so far, due to the ongoing collaboration among the municipality and the local corporation (E. ON SE), by paving a path for 4PA with the potential proactive role of academia and civic society. In Nilüfer, PPAP appears to be the suitable option as a result of several ongoing energy co-operatives jointly established with the university.

Considering mobility, another different business and social rationale from the perspective of stakeholders determines the strategic selection: the PPP model for Lausanne and Nilüfer, while 4PA is the most suitable model for Essen. According to the stakeholders' validation workshop, Lausanne shows great dependency on its DPP model in the city. The next step to revert this logic was the PPP, yet simply as an evolution on the business/social model of the city for this sector. Consequently, Lausanne aspires to include further involvement of stakeholders, as Eqlosion attempted in the workshop, by establishing further links and interactions. In Nilüfer, the situation was a bit more divided: the lack of sustainable mobility demands clearly signal a shift towards a PPP model, although several key stakeholders could see the potential of U/DC as well, insofar as an informal, socially-rooted, and highly-networked transport system called dolmuş—share taxis—works efficiently [135]. This informal mobility system would require a sharing economy platform based on data commons to enhance its socio-economic impact on the metropolitan area of Bursa. Essen was already implementing several mobility systems integrating citizens through parking and public transport apps.

Finally, in the ICT sector, Essen chose U/DC, whereas Lausanne and Nilüfer preferred PPP and PPAP, respectively. This sector witnessed the marginal selection of the DPP, acknowledging a weak potential to absorb the investment in data governance and regulation, while Essen embraced new initiatives on data commons (U/DC) as a way to take the lead in the post-GDPR context instead. Lausanne admitted its clear weakness in this field, and Nilüfer demonstrated its preliminary smart city platform project led by the university.

\section{Conclusions}

This article aimed to shed light on the helix frameworks from the SI perspective by extending the triple- and quadruple-helix frameworks through suggesting an evidence-based ex-novo framework called penta-helix, which has been comparatively operationalised in three case studies. Based on the penta-helix framework, this article showed the following for each case study: (i) a unique multistakeholder composition, degree of influence, and proactivity per helix; (ii) a diverse set of strategic preferences on business/social models per smart city sector; and (iii) a constant presence of the fifth helix as intermediaries, by concluding that (iv) there is a willingness among stakeholders to increasingly experiment with additional diverse democratic arrangements (beyond the PPP). 
Although extant literature on the European model of smart cities presents a detailed illustration of the multistakeholder policy frameworks [120], there has been little research to compare the helix frameworks and even less evidence-based data on analysing the stakeholders' compositions and strategic preferences in specific urban contexts. One of the major reasons for the lack of evidence might be the hegemonic assumptions around the self-referential PPP model. Considering the newness of opening up towards a wider approach, it can be assumed the consequences for this absence of rich approaches, which could be seen in the way the term stakeholder adopts a vacuum and apolitical significance [42]. This does not reflect the reality full of complex and intertwined interactions among stakeholders. In addition, it underestimates the agency and the transformational role that several stakeholders pervasively may take by germinating SI as an iterative joint multistakeholder process. Therefore, smart cities by themselves do not necessarily lead to greater democracy, as envisaged by advocates of the term long ago, but rather to a potential risk for generalising pervasive forms of algorithmic extractivism and surveillance capitalism [11], whose substantial aim are to monetise all bits of citizens' lives. Building on this, this article-by comparing three cities-provided evidence for demonstrating how their multistakeholder composition brings about a diverse set of strategic priorities resulting in different business/social models.

The literature review of the helix multistakeholder framework, and the resulting business/social models, helped in discussing various selected dimensions, which then opened up avenues to raise further findings that can inform future empirical research on this topic. In the prospects of future research addressing democratic legitimacy-related questions smart cities face, this article shed light on a further nuanced empirical demonstration regarding the penta-helix framework playing a role in creating less technocratic smart cities. The penta-helix thus represents in itself a methodological innovation with social added value by acknowledging that each city or region may present a different democratic context in which stakeholders operate and interact in relatively unique terms [1,54,110]. Apart from addressing the research questions, this article encourages scholars to follow the methodological rationale that was suggested by taking up comparative case study research that highlights novel analytical practices carried out in the broad SCC H2020 European framework bringing together no less than 93 European smart cities, which, in itself, is an opportunity to further explore the research questions elucidated. Especially, when a field is in the emergent stage, case studies offer rich comparative understanding and allow researchers to adopt exploratory approaches to describe novel frameworks like the suggested penta-helix.

In summary, this article, acknowledging the preliminary exploratory findings stemming from this intensive fieldwork action research study conducted in three European cities encourages critical scholars working in the SI field to engage in applied research pertaining to democratic smart city-building through the penta-helix framework. Consequently, the private sector, the public sector, academia, and civic society can come together-assisted by the fifth helix, intermediaries, social entrepreneurs, or/and activists, who can have the capacity to enhance the plurality towards a democratic smart city-and fulfil ambitions of a wide multiplicity of stakeholders who co-exist and act in the city. The research questions established in this article serve as a trigger for a much-needed push in influencing the H2020-SCC policy framework programme in augmenting the role that SI-stemming from the renowned European social market economy approach-plays in smart cities. Other researchers can actively reuse this research to match the growing contribution that SI makes at the grassroots level in building democratic smart cities in Europe [110].

Funding: This research was funded by European Commission (EC) under the Grant H2020-SCC-691735-REPLICATE and ESRC under the Grant Urban Transformations programme ES/M010996/1.

Acknowledgments: The author is deeply indebted to the city representatives, in particular, and to all stakeholders in Essen, Lausanne, and Nilüfer who kindly accepted participating through in -depth interviews and validation workshops in the period 2017-2018 within the EC-H2020-SCC-691735-REPLICATE project.

Conflicts of Interest: The author declares no conflict of interest. 


\section{Appendix A}

Table A1. Details of direct sources: Fieldwork action research through in-depth interviews and validation workshops from February 2017 to December 2018.

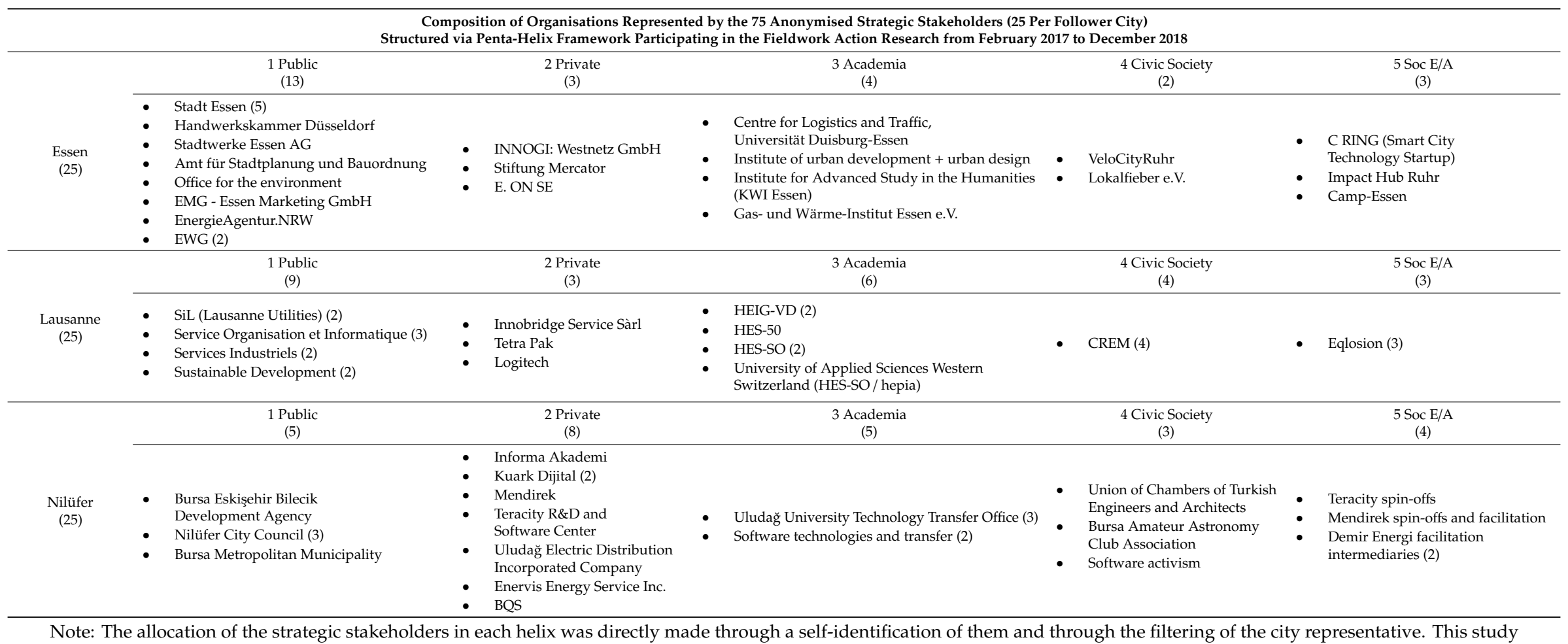

directly reflects this allocation made at the city level by the main active participants of the fieldwork action research process that took place from February 2017 to December 2018. 
Table A2. Questionnaire.

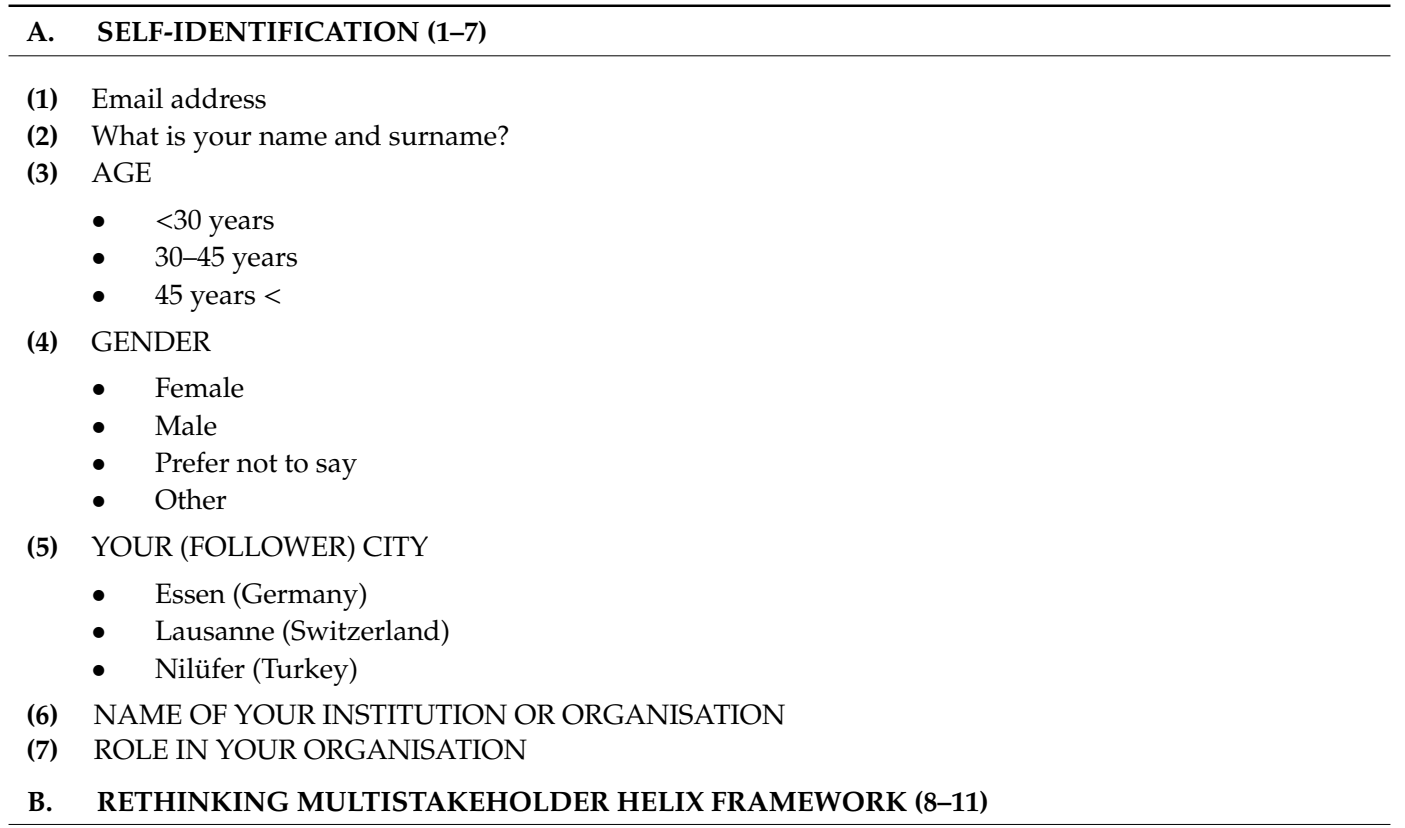

In this section, we will kindly ask you to answer to your question about the institutions/organizations operating in your (follower) city. Remember that the answers will be anonymised:

\section{(8) COMPOSITION (1st STRATEGIC DIMENSION)}

Could you please select the stakeholder group that you consider you belong to in the context of your (follower) city? (You can select more than one, if this is the case.)

1. Public sector: Local, regional, national authorities, and/or related institutions

2. Private sector: Firms, companies, and corporations

3. Academia: Science, technology, and knowledge centre (any discipline)

4. Civic Society: NGO, associations, civic groups (any kind of formal civic group)

5. Social Entrepreneurs/Activists/Bricoleurs/Assemblers working directly/indirectly with other stakeholders groups (in any kind of informal network)

(9) INFLUENCE (2nd STRATEGIC DIMENSION)

Which is/are the most influential(s) stakeholder group(s) in your (follower) city?

- Public

- Private

- Academia

- $\quad$ Civic Society

- Social Entrepreneurs/Activists

(10) PROACTIVITY (3rd STRATEGIC DIMENSION)

Could you please rate how proactive are these groups of stakeholders in your (follower) city?

- Public

- Private

- Academia

- Civic Society

- $\quad$ Social Entrepreneurs/Activists

Not at all

Sometimes

Always

(11) Could you please detail which organisation are you referring to? Name the institution/organisation, please.

C. RESULTING BUSINESS/SOCIAL MODELS (12-15)

(12) KNOWLEDGE ABOUT PPP (4th STRATEGIC DIMENSION)

Do you know what does Public Private Partnership (PPP) mean?

- Yes

- Maybe

- $\mathrm{No}$ 
Table A2. Cont.

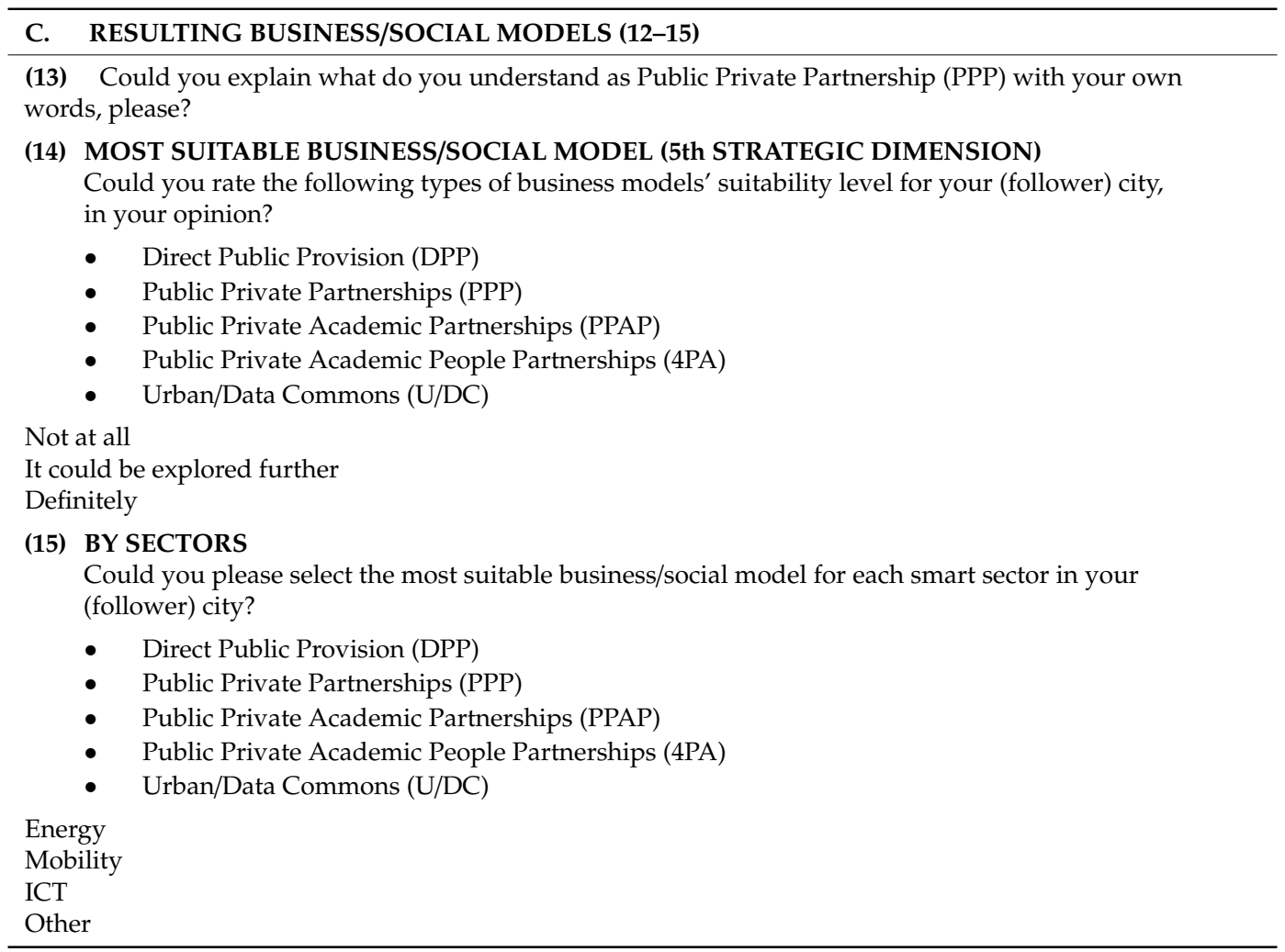

\section{References}

1. Habermas, J. The Lure of Technocracy; Polity Press: London, UK, 2015.

2. Albino, V.; Berardi, U.; Dangelico, R.M. Smart cities: Definitions, dimensions, performance, and initiatives. J. Urban Technol. 2015, 22, 3-21. [CrossRef]

3. Caragliu, A.; Del Bo, C.F. Smart innovative cities: The impact of smart city policies on urban innovation. Technol. Forecast. Soc. Chang. 2019, 142, 373-383. [CrossRef]

4. Desdemoustier, J.; Crutzen, N.; Giffinger, R. Municipalities' understanding of the Smart City concept: An exploratory analysis in Belgium. Technol. Forecast. Soc. Chang. 2019, 142, 129-141. [CrossRef]

5. Nesti, G.; Graziano, P.R. The democratic anchorage of governance networks in smart cities: An empirical assessment. Public Manag. Rev. 2019, 22, 648-667. [CrossRef]

6. Nilssen, M. To the smart city and beyond? Developing a typology of smart urban innovation. Technol. Forecast. Soc. Chang. 2018, 142, 98-104. [CrossRef]

7. Ranchordás, S. Nudging citizens through technology in smart cities. Int. Rev. Law Comput. Technol. 2019, 1-23. [CrossRef]

8. Trencher, G. Towards the smart city 2.0: Empirical evidence of using smartness as a tool for tackling social challenges. Technol. Forecast. Soc. Chang. 2018, 142, 117-128. [CrossRef]

9. Vanolo, A. Is there anybody out there? The place and role of citizens in tomorrow's smart cities. Futures 2016, 82, 26-36. [CrossRef]

10. Komninos, N.; Kakderi, C. Smart Cities in the Post-Algorithmic Era: Integrating Technologies, Platforms and Governance; Edward Elgar: Chentelham, UK, 2019.

11. Zuboff, S. The Age of Surveillance Capitalism: The Fight for a Human Future at the New Frontier of Power; Profile: London, UK, 2019.

12. Kitchin, R. The real-time city? Big data and smart urbanism. Geo J. 2014, 79, 1-14. [CrossRef]

13. Janssen, M.; Kuk, G. The challenges and limits of big data algorithms in technocratic governance. Gov. Inf. Q. 2016, 33, 371-377. [CrossRef]

14. Johnson, P.A.; Robinson, P.J.; Philpot, S. Type, tweet, tap, and pass: How smart city technology is creating a transactional citizen. Gov. Inf. Q. 2019, 37, 101414. [CrossRef] 
15. Madsen, A.K. Data in the smart city: How incongruent frames challenge the transition from ideal to practice. Big Data Soc. 2018, 5, 1-13. [CrossRef]

16. Barns, S. Making Sense of Platform Intermediation. In Platform Urbanism: Negotiating Platform Ecosystems in Connected Cities; Springer: Singapore, 2020.

17. Fields, D.; Bissell, D.; Macrorie, R. Platform methods: Studying platform urbanism outside the black box. Urban Geogr. 2020, 41, 462-468. [CrossRef]

18. Stehlin, J.; Hodson, M.; McMeekin, A. Platform mobilities and the production of urban space: Toward a typology of platformization trajectories. Environ. Plan. A Econ. Space 2020, 52, 1250-1268. [CrossRef]

19. European Commission. Creating the Links for Scaling Smart Cities Solutions; H2020: Eindhoven, The Netherlands, 2016.

20. European Commission. The Making of a Smart City: Best Practices across Europe; European Commission: Brussels, Belgium, 2017.

21. European Commission. The Making of a Smart City: Policy Recommendations; European Commission: Brussels, Belgium, 2017.

22. European Commission. Co-Creating Innovative Public Services for Citizens and Businesses; European Commission: Luxembourg, 2019.

23. EIP-SCC. Towards a Joint Investment Programme for European Smart Cities: A Consultation Paper to Stimulate Action; European Commission: Brussels, Belgium, 2016.

24. Mazzucato, M. Mission-Oriented Research E Innovation in the European Union: A Problem-Solving Approach to Fuel Innovation-Led Growth; European Commission: Brussels, Belgium, 2018.

25. Vandervyvere, H. Recommendations on EU R\&I and Regulatory Policies: Why May Replication (Not) Be Happening? EU Smart Cities Information System. D32. 3A. 2017. Available online: https://smartcities-infosystem.eu/newsroom/news/scis-policy-analysis-\%E2\%80\%93-why-mayreplication-not-be-happening (accessed on 21 December 2019).

26. SCIS. Lighthouse Projects. 2019. Available online: https://smartcities-infosystem.eu/scc-lighthouse-projects (accessed on 21 December 2019).

27. Forrer, J.; Kee, J.E.; Newcomer, K.E.; Boyer, E. Public-private partnerships and public accountability question. Public Adm. Rev. 2010, 70, 475-484. [CrossRef]

28. Frug, G.E. The City: Private or Public? LSE Cities Working Papers: London, UK, 2017.

29. Goldstein, B.T.; Mele, C. Governance within public-private partnerships and the politics of urban development. Space Polity 2016, 20, 194-211. [CrossRef]

30. Grossi, G.; Pianezzi, D. Smart cities: Utopia or neoliberal ideology? Cities 2017, 69, 79-85. [CrossRef]

31. Hall, D. Why Public-Private Partnerships Don't Work: The Many Advantages of the Public Alternative; University of Greenwich: London, UK; PSIRU (Public Services International Research Unit): Greenwich, UK, 2015.

32. Mazzucato, M. The Entrepreneurial State: Debunking Public vs. Private Sector Myths; AnthenPress: London, UK, 2015.

33. Rossi, U. The variegated economics and the potential politics of the smart city. Territ. Politics Gov. 2016, 4, 337-353. [CrossRef]

34. Kennedy, H.; Poell, T.; Van Dijck, J. Data and agency. Big Data Soc. 2015, 2, 1-7. [CrossRef]

35. Paskaleva, K.; Cooper, I.; Linde, P.; Peterson, B.; Götz, C. Stakeholder engagement in the smart city: Making living labs work. In Transforming City Governments for Successful Smart Cities; Springer: Cham, Switzerland, 2015.

36. Kummitha, R.K.R. Smart cities and entrepreneurship: An agenda for future research. Technol. Forecast. Soc. Chang. 2019, 149, 119763. [CrossRef]

37. Harvey, D. The new urbanism and the communitarian trap. Harv. Des. Mag. 1997, 1, 68-69.

38. Borsboom-Van Beurden, J.; Kallaos, J.; Gindroz, B.; Costa, S.; Riegler, J. Smart City Guidance Package: A Roadmap for Integrated Planning and Implementation of Smart City Projects; EIP-SCC: Brussels, Belgium, 2019.

39. Hollands, R.G. Will the real smart city please stand up? City 2008, 12, 303-320. [CrossRef]

40. Hollands, R.G. Critical interventions into the corporate smart city. Camb. J. Reg. Econ. Soc. 2014, 8, 61-77. [CrossRef]

41. Kitchin, R.; Coletta, C.; Evans, L.; Heaphy, L.; Mac Donncha, D. Smart Cities, Urban Technocrats, Epistemic Communities and Advocacy Coalitions; The Programmable City Working Paper, 2017, Paper 26, Maynooth. Available online: https://osf.io/preprints/socarxiv/rxk4r/ (accessed on 8 September 2020). 
42. Cardullo, P.; Kitchin, R. Smart urbanism and smart citizenship: The Neoliberal Logic of 'Citizen-Focused' Smart Cities in Europe. Environ. Plan. C Politics Space 2019, 37, 813-830, The Programmable City Working Paper, 2018, Paper 39, Maynooth. [CrossRef]

43. Engelbert, J.; Van Zoonen, L.; Hirzalla, F. Excluding citizens from the European smart city: The discourse practices of pursuing and granting smartness. Technol. Forecast. Soc. Chang. 2018, 142, 347-353. [CrossRef]

44. Eubanks, V. Automating Inequality: How High-Tech Tools Profile, Police, and Punish the Poor; St. Martin's Press: New York, NY, USA, 2017.

45. Kempin Reuter, T. Human rights and the city: Including marginalized communities in urban development and smart cities. J. Hum. Rights 2019, 18, 382-402. [CrossRef]

46. Kourtit, K.; Nijkamp, P. Smart cities in the innovation age. Innov. Eur. J. Soc. Sci. Res. 2012, 25, 93-95. [CrossRef]

47. Calzada, I. (Un)Plugging smart cities with urban transformations: Towards multistakeholder city-regional complex urbanity? URBS Rev. Estud. Urbanos Cienc. Soc. 2016, 6, 25-45.

48. Calzada, I. Deciphering smart city citizenship: The techno-politics of data and urban co-operative platforms. Rev. Int. Estud. Vascos RIEV 2018, 63, 42-81. [CrossRef]

49. Calzada, I. From smart cities to experimental cities? In Co-Designing Economies in Transition: Radical Approaches in Dialogue with Contemplative Social Sciences; Giorgino, V.M.B., Walsh, Z., Eds.; Springer: Cham, Switzerland, 2018. [CrossRef]

50. Calzada, I. Local entrepreneurship through a multistakeholders' tourism living lab in the post-violence/peripheral era in the Basque Country. Reg. Sci. Policy Pract. 2018, 11, 451-466. [CrossRef]

51. Calzada, I. (Smart) citizens from data providers to decision-makers? The case study of Barcelona. Sustainability 2018, 10, 3252. [CrossRef]

52. Calzada, I.; Cowie, P. Beyond smart and data-driven city-regions? Rethinking stakeholder-helixes strategies. Reg. Mag. 2017, 308, 25-28. [CrossRef]

53. SUI (Smart Urban Intermediaries). Smart Cities, Social Innovation and Smart Urban Development; University of Edinburgh: Edinburgh, UK, 2018.

54. Calzada, I. Replicating Smart Cities: The City-to-City Learning Programme in the Replicate EC-H2020-SCC Project. Smart Cities 2020, 3, 978-1003. [CrossRef]

55. Butzlaff, F. Between empowerment and abuse: Citizen participation beyond the post-democratic turn. Democratization 2020, 27, 477-493. [CrossRef]

56. Angelidou, M.; Psaltoglou, A. An empirical investigation of social innovation initiatives for sustainable urban development. Sustain. Cities Soc. 2017, 33, 113-125. [CrossRef]

57. Bartels, K. Transforming the relational dynamics of urban governance: How social innovation research can create a trajectory for learning and change? Urban Stud. 2020. [CrossRef]

58. Bund, E.; Gerhard, U.; Hoelscher, M. A methodological framework for measuing social innovation. Hist. Soc. Res. 2015, 40, 48-78.

59. Caroli, M.G.; Fracassi, E.; Maiolini, R.; Pulino, S.C. Exploring social innovatoin components and attributes: A taxonomy proposal. J. Soc. Entrep. 2018, 9, 94-109. [CrossRef]

60. Christmann, G.B. Introduction: Struggling with innovations. Social innovations and conflicts in urban development and planning. Eur. Plan. Stud. 2020, 28, 423-433. [CrossRef]

61. Engelbrecht, H.J. The (social) innovation - subjective well-being nexus: Subjective well-being impacts as an additional assessment metric of technological and social innovations. Innov. Eur. J. Soc. Sci. Res. 2018, 31, 317-332. [CrossRef]

62. European Commission. Social innovation research in the European Union. Approaches, Findings and Future Directions; Publications Office of the European Union: Luxembourg, 2010.

63. Keith, M.; Calzada, I. Back to the 'Urban Commons'? Social Innovation through New Co-Operative Forms in Europe; Bridging European Urban Transformations. ESRC: Brussels, Belgium, 2018. [CrossRef]

64. Moulaert, F.; MacCallum, D. Advanced Introduction to Social Innovation; Edward Elgar: Cheltenham, UK, 2019.

65. Moulaert, F.; Martinelli, F.; González, S.; Swyngedouw, E. Introduction: Social Innovation and Governance in European Cities. Eur. Urban Reg. Stud. 2007, 14, 195-209. [CrossRef]

66. Moulaert, F.; MacCallum, D.; Mehmood, A.; Hamdouch, A. The International Handbook on Social Innovation: Collective Action, Social Learning and Transdisciplinary Research; Edward Elgar: Cheltenham, UK, 2013.

67. Nicholls, A.; Murdock, A. The Nature of Social Innovation; Palgrave Macmillan: London, UK, 2012. 
68. Pel, B.; Wittmayer, J.; Dorland, J.; Soggard Jorgensen, M. Unpacking the social innovation ecosystem: An empirically grounded typology of empowering network constellations. Innov. Eur. J. Soc. Sci. Res. 2019, 33, 311-336. [CrossRef]

69. Preskill, H.; Beer, T. Evaluating Social Innovation; Center for Evaluation Innovation: Washington, DC, USA, 2012.

70. Sabato, S.; Vanhercke, B.; Verschraegen, G. Connecting entrepreneurship with policy experimentation? The EU framework for social innovation. Innov. Eur. J. Soc. Sci. Res. 2017, 30, 147-167. [CrossRef]

71. Schubert, C. Social innovation. A new instrument of social change. In Innovation society today, Perspectives, Fields, and Cases; Rammert, W., Windeler, A., Hutter, M., Knoblauch, H., Eds.; Springer VS: Wiesbaden, Germany, 2018.

72. Terstriep, J.; Rehfeld, D.; Kleverbeck, M. Favourable social innovation ecosystem(s)—An explorative research. Eur. Plan. Stud. 2020, 28, 881-905. [CrossRef]

73. Vadrot, A.B.M. Re-thinking the conditions for social change and innovation. Innov. Eur. J. Soc. Sci. Res. 2020, 33, 1-3. [CrossRef]

74. Mihci, H. Is measuring social innovation a mission impossible? Innov. Eur. J. Social Sci. Res. 2019, 33, 337-367. [CrossRef]

75. Moulaert, F.; Mehmood, A. Towards a social innovation (SI) based epistemology in local development analysis: Lessons from twenty years of EU research. Eur. Plan. Stud. 2020, 28, 434-453. [CrossRef]

76. Poppen, F.; Decker, R. The intermediary as an institutional entrepreneur: Institutional change and stability in triple-helix cooperation. Triple Helix 2018, 5, 9. [CrossRef]

77. Van de Broeck, P.; Mehmood, A.; Paidakaki, A.; Parra, C. Social Innovation as Political Transformation through for a Better World; Edward Elgar Publishing: Cheltenham, UK; Northampton, MA, USA, 2019.

78. Domanski, D.; Howaldt, J.; Kaletka, C. A comprehensive concept of social innovation and its implicationns for the local context-on the growing importance of social innovation ecosystems and infrastructures. Eur. Plan. Stud. 2020, 28, 454-474. [CrossRef]

79. Baack, S. Datafication and empowerment: How the open data movement re-articulates notions of democracy, participation, and journalism. Big Data Soc. 2015, 2, 1-11. [CrossRef]

80. Etzkowitz, H.; Leydesdorff, L. The dynamics of innovation: From national systems and "Mode 2" to a triple helix of university-industry-government relations. Res. Policy 2000, 29, 109-123. [CrossRef]

81. Deakin, M.; Mora, L.; Reid, A. The research and innovation of smart specialisation strategies: The transition from the triple to quadruple helix. In Proceedings of the 27th International Scientific Conference on Economic and Social Development, Rome, Italy, 1-2 March 2018.

82. Turner, B.S. Contemporary Citizenship: Four Types. J. Citizsh. Glob. Stud. 2017, 1, 10-23. [CrossRef]

83. Calzada, I.; Almirall, E. Data Ecosystems for Protecting European Citizens' Digital Rights. Transform. Gov. People Process. Policy TGPPP 2020, 14, 133-147. [CrossRef]

84. Calzada, I.; Almirall, E. Barcelona's grassroots-led urban experimentation: Deciphering the 'data commons' policy scheme. Zenodo 2019. Data for Policy 2019, 11-12 June, London, UCL. [CrossRef]

85. Etzkowitz, H.; Ranga, M.; Dzisah, J.; Zhou, C. University-industry-government interaction: The triple helix model of innovation. Asia Pac. Tech Monit. 2007, 24, 14-23.

86. Lawton Smith, H.; Leydesdorff, L. The triple helix in the context of global change: Dynamics and challenges. Prometheus 2014, 32, 321-336. [CrossRef]

87. Lewontin, R.C. The Triple Helix: GENE, Organism, and Environment; Harvard University Press: Cambridge, MA, USA, 2000.

88. Leydesdorff, L. The triple helix, quadruple helix, ... , and an N-tuple of helices: Explanatory models for analyzing the knowledge-based economy? J. Knowl. Econ. 2012, 3, 25-35. [CrossRef]

89. Leydesdorff, L.; Deakin, M. The triple-helix model of smart cities: A neo-evolutionary perspective. J. Urban Technol. 2011, 18, 53-63. [CrossRef]

90. Leydesdorff, L.; Fritsch, M. Measuring the knowledge base of regional innovation systems in Germany in terms of a triple helix dynamics. Res. Policy 2006, 35, 1538-1553. [CrossRef]

91. Deakin, M. Smart cities: The state-of-the-art and governance challenge. Triple Helix 2014, 1, 1-16. [CrossRef]

92. Grimm, R.; Fox, C.; Baines, S.; Albertson, K. Social innovation, an answer to contemporary societal challenges? Locating the concept in theory and practice. Innov. Eur. J. Soc. Sci. Res. 2013, 26, 436-455. [CrossRef] 
93. Swyngedouw, E. Governance innovation and the citizen: The janus face of governance-beyond-the-state. Urban Stud. 2005, 42, 1991-2006. [CrossRef]

94. Lombardi, P.; Giordano, S.; Caragliu, A.; Del Bo, C.; Deakin, M.; Nijkamp, P.; Kourtit, K. An Advanced Triple-Helix Network Model for Smart Cities Performance; Research Memorandum 2011-45; Vrije Universiteit: Amsterdam, The Netherlands, 2011.

95. Goddard, J.; Kempton, L. The Civic University: Universities in Leadership and Management of Place; RR2016/01; University of Warwick: Warwick, UK, 2016. [CrossRef]

96. Kummitha, R.K.R.; Crutzen, N. Smart cities and the citizen-driven internet of things: A qualitative inquiry into an emerging smart city. Technol. Forecast. Soc. Chang. 2019, 140, 44-53. [CrossRef]

97. Vallance, P.; Tewdwr-Jones, M.; Kempton, L. Building collaborative platforms for urban innovation: Newcastle City Futures as a quadruple helix intermediary. Eur. Urban Reg. Stud. 2020, 1-7. [CrossRef]

98. Afonso, O.; Monteiro, S.; Thompson, M. A growth model for the quadruple helix. J. Bus. Econ. Manag. 2012, 13, 849-865. [CrossRef]

99. Ahonen, L.; Hämäläinen, T. CLIQ: A practical approach to the quadruple helix and more open innovation. In Sustaining Innovation. Collaboration Models in a Complex World; Macgregor, S., Carleton, T., Eds.; Springer: Cham, Switzerland, 2012.

100. Carayannis, E.G.; Campbell, D.F.J. Mode 3 Knowledge Production in Quadruple Helix Innovation Systems; Springer: New York, NY, USA, 2012; Volume 7, pp. 1-63. [CrossRef]

101. Cavallini, S.; Soldi, R.; Friedl, J.; Volpe, M. Using the Quadruple Helix Approach to Accelerate the Transfer of Research and Innovation Results to Regional Growth; Publications Office of the EU: Luxembourg, 2016.

102. Sandoval, M. Entrepreneurial activism? Platform cooperativism between subversion and co-optation. Crit. Sociol. 2019, 46, 801-817. [CrossRef]

103. Siapera, E.; Papadopoulou, L. Entrepreneurialism or cooperativism? J. Pract. 2016, 10, 178-195. [CrossRef]

104. Iaione, C. Governing the Urban Commons. Ital. J. Public Law 2015, 7, 1-53.

105. Bollier, D. Commoning as a Transformative Social Paradigm. The Next System Project. Available online: http://www.thenextsystem.org/commoning-as-a-transformative-social-paradigm/ (accessed on 21 July 2020).

106. Calzada, I.; Cobo, C. Unplugging: Deconstructing the smart city. J. Urban Technol. 2015, 22, 23-43. [CrossRef]

107. Calzada, I.D. Report on Conclusions of the Interviews and the Validation Workshops; University of Oxford: Oxford, UK, 2018.

108. Carayannis, E.G.; Campbell, D.F.J. Triple helix, quadruple helix and quintuple helix and how do knowledge, innovation and the environment relate to each other? A proposed framework for a trans-disciplinary analysis of sustainable development and social ecology. Int. J. Soc. Ecol. Sustain. Dev. (IJSESD) 2010, 1, 41-69. [CrossRef]

109. Halibas, A.S.; Sibayan, R.O.; Maata, R.L.R. The penta helix model of innovation in Oman: An HEI perspective. Interdiscip. J. Inf. Knowl. Manag. 2017, 12, 159-172. [CrossRef]

110. Calzada, I. Smart City Citizenship; Elsevier Science Publishing Co Inc: Cambridge, MA, USA, 2020; ISBN 978-0-12-815300-0.

111. Ostrom, E. Governing the Commons: The Evolution of Institutions for Collective Action; Cambridge University Press: Cambridge, UK, 1990.

112. Tonkovic, A.M.; Veckie, E.; Veckie, V.W. Applications of Penta Helix Model in Economic Development. Econ. East. Croat. Yesterday Today Tommorow 2015, 4, 385-393.

113. Donald, B.; Glasmeier, A.; Gray, M.; Lobao, L. Austerity in the city: Economic crisis and urban service decline? Camb. J. Reg. Econ. Soc. 2014, 7, 3-15. [CrossRef]

114. Brogaard, L. The impact of innovation training on successful outcomes in public-private partnerships. Public Manag. Rev. 2017, 19, 1184-1205. [CrossRef]

115. Prainsack, B. Logged out: Ownership, exclusion and public value in the digital data and information commons. Big Data Soc. 2019, 6, 1-15. [CrossRef]

116. Murphy, G.B.; Tocher, N.; Ward, B. An Examination of Public Private Academic Partnerships: Does Program Success Enhance University Performance Outcomes? Public Organ. Rev. 2016, 16, 95-115. [CrossRef]

117. Anderson, T.S.; Michael, E.K.; Peirce, J.J. Innovative approaches for managing public-private academic partnerships in big science and engineering. Public Organ. Rev. 2012, 12, 1-22. [CrossRef]

118. Callon, M. The role of lay people in the production and dissemination of scientific knowledge. Sci. Technol. Soc. 1999, 4, 81-94. [CrossRef] 
119. Ng, S.T.; Wong, J.M.W.; Wong, K.K.W. A public private people partnerships (P4) process framework for infrastructure development in Hong Kong. Cities 2013, 31, 370-381. [CrossRef]

120. Späth, P.; Knieling, J. How EU-funded smart city experiments influence modes of planning for mobility: Observations from Hamburg. Urban Transform. 2020, 2, 1-17. [CrossRef]

121. Voorberg, W.H.; Bekkers, V.J.J.M.; Tummers, L.G. A Systematic Review of Co-Creation and Co-Production: Embarking on the social innovation journey. Public Manag. Rev. 2015, 17, 1333-1357. [CrossRef]

122. Allen, B.; Tamindael, L.E.; Bickerton, S.H.; Cho, W. Does citizen coproduction lead to better urban services in smart cities projects? An empirical study on e-participation in a mobile big data platform. Gov. Inf. Q. 2020, 37, 101412. [CrossRef]

123. Bollier, D.; Helfrich, S. Patterns of commoning: The commons strategies group. Available online: http://www. bollier.org/blog/spanish-translation- $\%$ e2\%80\%9cthink-commoner\%e2\%80\%9d-now-published (accessed on 30 September 2020).

124. Labaeye, A. Sharing Cities: Using Urban Data to Reclaim Public Space as a Commons. Available online: http: //www.shareable.net/blog/sharing-cities-using-urban-data-to-reclaim-public-space-as-a-commons (accessed on 21 December 2019).

125. Barcelona City Council. Decidim. Available online: https://www.decidim.barcelona/ (accessed on 21 December 2019).

126. Calzada, I. Data spaces and democracy. RSA J. 2019, 2, 40-43. [CrossRef]

127. Dellenbaugh, M.; Kip, M.; Bieniok, M. Urban Commons: Moving beyond State and Market; Birkhäuser: Basel, Switzerland, 2016.

128. Pestoff, V.; Brandsen, T.; Verschuere, B. New Public Governance, the Third Sector, and Co-Production; Routledge: Oxon, UK, 2013.

129. Higdem, U. The co-creation of regional futures: Facilitating action research in regional foresight. Futures 2014, 57, 41-50. [CrossRef]

130. Moulaert, F. Social Innovation: Institutionally Embedded, Territorialy (Re)produced. In Social Innovation and Territorial Development; MacCallum, D., Moulaert, F., Hillier, J., Haddock, S.V., Eds.; Routledge: London, UK, 2009.

131. Yin, R.K. Applications of Case Study Research; SAGE: London, UK, 2011.

132. Essen. Available online: https://replicate-project.eu/2nd-session-the-new-smelters-of-the-coal-heartland/ (accessed on 21 December 2019).

133. Lausanne. Available online: https://replicate-project.eu/4th-session-roadmap-for-the-realization-of-aneco-district-including-development-of-medium-depth-geothermal-energy-in-urban-areas/ (accessed on 21 December 2019).

134. Nilüfer. Available online: https://replicate-project.eu/6th-session-socio-economic-development-from-below/ (accessed on 21 December 2019).

135. Özbilen, B. Integration of Dolmus as a Paratransit Mode to the Existing Public Transport Network: Ankara Example; The Middle East Technical University: Ankara, Turkey, 2016.

(C) 2020 European Commission. Licensee MDPI, Basel, Switzerland. This is an open access article distributed under the terms of the Creative Commons Attribution IGO License (http://creativecommons.org/licenses/by/3.0/igo/legalcode), which permits unrestricted use, distribution, and reproduction in any medium, provided the original work is properly cited. In any reproduction of this article there should not be any suggestion that EC or this article endorse any specific organisation or products. The use of the EC logo is not permitted. This notice should be preserved along with the article's original URL.z. 